Additional Perspectives articles for Influenza: The Cutting Edge book collection are available at http://perspectivesinmedicine.cshlp.org/cgi/collection/influenza_the_cutting_edge.

\title{
Immunity to Influenza Infection in Humans
}

\author{
David J. Topham, ${ }^{1}$ Marta L. DeDiego, ${ }^{2}$ Aitor Nogales, ${ }^{3}$ Mark Y. Sangster, ${ }^{1}$ and Andrea Sant ${ }^{1}$ \\ ${ }^{1}$ David H. Smith Center for Vaccine Biology and Immunology, Department of Microbiology and Immunology, \\ University of Rochester Medical Center, Rochester, New York 14642, USA \\ ${ }^{2}$ Centro Nacional de Biotecnología, Consejo Superior de Investigaciones Cientificas, 28049 Madrid, Spain \\ ${ }^{3}$ Instituto Nacional de Investigación y Tecnologia Agraria y Ailmentaria, 28040 Madrid, Spain \\ Correspondence: david_topham@urmc.rochester.edu
}

This review discusses the human immune responses to influenza infection with some insights from studies using animal models, such as experimental infection of mice. Recent technological advances in the study of human immune responses have greatly added to our knowledge of the infection and immune responses, and therefore much of the focus is on recent studies that have moved the field forward. We consider the complexity of the adaptive response generated by many sequential encounters through infection and vaccination.

$\mathrm{D}$ espite the widespread and readily available seasonal influenza vaccination in the United States and other countries, influenza continues to cause annual epidemics. In the United States alone, influenza viruses are estimated to infect between 9.2 million and 35.6 million people, resulting in 140,000-710,000 hospitalizations and 12,000-56,000 deaths (see cdc.gov/ flu/about/burden/index.html). Currently, there are four strains of the seasonal virus that widely circulate, two are of the influenza A (IAV) lineage, and two are of the influenza B lineage (see cdc.gov/flu/about/burden/index.html). Human seasonal IAVs are comprised of two antigenically distinct variants as characterized by their surface glycoproteins, hemagglutinin (HA) and neuraminidase (NA), with $\mathrm{H} 1 \mathrm{~N} 1$ and $\mathrm{H} 3 \mathrm{~N} 2$ IAVs in circulation. Influenza $B$ viruses fall into two lineages, influenza B/Yamagata and $\mathrm{B} / \mathrm{Victoria}$. $\mathrm{H} 3 \mathrm{~N} 2$ viruses are the most antigenically variable and frequent drift variants emerge
(Both et al. 1983; DeDiego et al. 2016a; Allen and Ross 2018). H1N1 is relatively more stable antigenically, although drift still occurs (Carrat and Flahault 2007; Clark et al. 2017a; Suptawiwat et al. 2018). Influenza B viruses have been the most antigenically stable, although the reasons for these differences in antigenic stability among influenza $\mathrm{A}$ and $\mathrm{B}$ viruses are not known. There is an influenza $\mathrm{C}$ virus strain that can infect humans, but it is rare and infection does not result in any significant disease (see cdc.gov/flu/about/ burden/index.html).

Currently, licensed vaccines against influenza carry either three $(\mathrm{H} 1 \mathrm{~N} 1, \mathrm{H} 3 \mathrm{~N} 2$, and $\mathrm{B})$ or four (H1N1, H3N2, and two Bs) strains of the virus (see cdc.gov/flu/about/burden/index .html). Even in areas with widespread vaccination, infections continue to occur as a result of poor antigenic match to the circulating strains (particularly for $\mathrm{H} 3 \mathrm{~N} 2$ ), as well as poor responses to vaccination (DeDiego et al. 2016a).

Editors: Gabriele Neumann and Yoshihiro Kawaoka

Additional Perspectives on Influenza: The Cutting Edge available at www.perspectivesinmedicine.org

Copyright (C) 2021 Cold Spring Harbor Laboratory Press; all rights reserved; doi: 10.1101/cshperspect.a038729

Cite this article as Cold Spring Harb Perspect Med 2021;11:a038729 
D.J. Topham et al.

People most at risk for severe disease and complications from influenza infection tend to be the very young $(<6$ yr of age [yoa]), older adults ( $>65$ yoa), and those with underlying health conditions such as diabetes, cardiovascular disease, and pregnancy (Abelleira et al. 2019; Kytömaa et al. 2019; Mertz et al. 2019).

Immunity to influenza is comprised of both the innate and adaptive components. Humans typically acquire adaptive immunity to influenza in the first years of life (birth to 10 yoa) consisting of antiviral antibodies, memory $\mathrm{B}$ cells (MBCs), and memory $\mathrm{CD}^{+}$and $\mathrm{CD}^{+} \mathrm{T}$ cells Innate immune responses are the first line of defense during infection and consist of types I and III interferon (IFN) production by infected cells and immune cells such as macrophages and specialized dendritic cells (DCs) (Fonteneau et al. 2003; Lui et al. 2009). The interferons induce a paracrine antiviral response, making cells more resistant to infection (Ramos et al. 2019), as well as working in concert with inflammatory chemokines that recruit innate immune cells such as neutrophils to the site of infection (Sprenger et al. 1996; Ichikawa et al. 2013; Lim et al. 2015). These innate immune responses can restrain virus replication until effector $\mathrm{T}$ cells and antibodies reach the tissue. Infections can last as long as 10-21 d in young naive subjects, and typically $5-7 \mathrm{~d}$ in those with preexisting immunity (Little et al. 1994; Ivan et al. 2013). Human influenza viruses have strong countermeasures to the antiviral effects of the innate immune response, which vary in effectiveness and affect viral pathogenesis and transmission (DeDiego et al. 2016b; Nogales et al. 2017a, 2018b).

\section{HOST INNATE IMMUNE RESPONSES AFTER IAV INFECTION}

\section{Host Innate Immune Responses and IAV Pathogenesis}

Innate immune responses lead to the expression of interferon-stimulated genes (ISGs) and inflammatory cytokines, which restrict virus replication. However, an excessive production of these proteins, mainly inflammatory cytokines, is associated with severe pathogenesis or mortality.
An exacerbated proinflammatory response can lead to acute respiratory distress syndrome (ARDS), which is the main cause of death in IAV-infected patients (Mauad et al. 2010; To et al. 2010). Most of the patients infected with the $2009 \mathrm{H} 1 \mathrm{~N} 1$ pandemic virus experienced a mild disease, which usually resolved in few weeks. However, severe disease occurred in some patients. The levels of interleukin (IL)-1 receptor antagonist protein (IL1RA), IL-6, tumor necrosis factor (TNF), IL-8, monocyte chemoattractant protein 1 (MCP-1)/CCL2, macrophage inflammatory protein $1 \mathrm{~B}$ (MIP-1 $\beta$ )/ CCL4, and IFN- $\gamma$-inducible protein 10 (IP10)/CXCL10 and apoptosis were up-regulated in the lungs from these fatal cases (Gao et al. 2013). Similarly, significantly higher levels of granulocyte colony-stimulating factor (G-CSF), IL-1, IL-6, IL-10, IL-15, MCP-1, and TNF were measured in serum of fatal cases (To et al. 2010). IFN- $\gamma$, IL-8, IL-9, IL-17, IL-6, TNF- $\alpha$, IL-15, and IL-12p70 responses were found in hospitalized patients versus those with mild disease (Bermejo-Martin et al. 2009). Severe disease in subjects infected with the H5N1 virus was also correlated with the levels of IL-8, IP-10, and monokine induced by IFN- $\gamma$ (MIG)/CXCL9 and MCP-1 (chemoattractants of monocytes and macrophages [de Jong et al. 2006]). H7N9 IAV infection is associated with early high levels of IL-6, IL-8, and MIP- $1 \beta$ in serum (Wang et al. 2014) and is correlated with pharyngeal virus load (Shen et al. 2014). Similarly, the high mortality rate observed in young adults during the 1918 pandemic has been attributed to the induction of a dysregulated pro-inflammatory response based upon experimental studies in various naive animal models using the reconstructed 1918 influenza virus (Kash et al. 2006; Kobasa et al. 2007; de Wit et al. 2018).

\section{IAV NS1 Protein}

The NS1 protein is translated from the mRNA synthesized from IAV segment 8 (Lamb and Lai 1980). This protein is most often a 230 -amino acid protein (Marc 2014). However, mutations that either suppress the stop codon at position 231 or create a premature stop codon result 
in length variations (Marc 2014). For instance, from the late 1940s until the middle of the 1980s, NS1 of human H1N1 IAV encoded at the carboxyl terminus, a 7-amino acid extension, being this protein 237 amino acids in length (Lohrmann et al. 2013; Marc 2014). In contrast, the NS1 protein of the $2009 \mathrm{pH} 1 \mathrm{~N} 1$, like that of most swine H1N1 IAV, has only 219 amino acids (Lohrmann et al. 2013; Marc 2014; Chauché et al. 2018).

The major function of NS1 is to antagonize host innate immune responses during infection, and this occurs at multiple stages of IFN production and signaling cascades. IAVs lacking or expressing truncated forms of NS1 (GarcíaSastre et al. 1998; Talon et al. 2000b), expressing reduced levels of NS1 (Nogales et al. 2014), or encoding amino acid mutations affecting NS1 functions (Nogales et al. 2014, 2017b; DeDiego et al. 2016a) are severely impaired in cells competent in the production of type I IFN, whereas they show similar levels of replication compared with viruses with wild-type NS1 in type I IFNdeficient cells (e.g., Vero cells) (García-Sastre et al. 1998).

NS1 inhibits RIG-I-mediated signaling and subsequent induction of type I IFNs. Specifically, the NS1 protein inhibits retinoic acid-inducible gene I (RIG-I) activation by sequestration of this RNA helicase and its activating ligand (Mibayashi et al. 2007; Opitz et al. 2007). Furthermore, the NS1 protein inhibits RIG-I ubiquitination mediated by TRIM25 and riplet, which is crucial for maximal type I and III IFNs' expression during viral infection (Gack et al. 2009; Rajsbaum et al. 2012; Koliopoulos et al. 2018). NS1 also interferes with functions of important intracellular antiviral ISGs, including protein kinase $\mathrm{R}$ (PKR) and oligoadenylate synthase (OAS). PKR is activated by double-strand RNA (dsRNA) or by the cellular protein activator of the interferon-induced PKR (PACT), resulting in autophosphorylation and phosphorylation of cellular proteins, including the $\alpha$ subunit of the eukaryotic initiation factor 2 (eIF2 $\alpha$ ) (Patel and Sen 1998). This phosphorylation leads to inhibition of protein synthesis, including viral proteins, in infected cells. The RNA-binding domain of NS1 can bind to viral RNA and avoid detection by PKR (Lu et al. 1995). It also binds to PKR itself via residues $123-127$ and 35 and 46 and inhibits PKR-mediated viral mRNA suppression and apoptosis (Bergmann et al. 2000; Li et al. 2006; Min et al. 2007; Schierhorn et al. 2017). Activation of OAS by dsRNA produces poly(A) chains with $2^{\prime}-5^{\prime}$ phosphodiester bonds (Clemens and Williams 1978), which bind to and activate constitutively expressed ribonuclease L (RNaseL), leading to the cleavage of viral and cellular single-stranded RNA (ssRNA), resulting in inhibition of virus replication (Silverman and Weiss 2014). OAS can also be blocked by influenza NS1. The RNA-binding domain of NS1 can outcompete the RNA binding capacity of OAS, thereby inhibiting the antiviral response (Min and Krug 2006).

NS1 blocks the inhibitor of kappa $\beta$ kinase (IKK) subunit $\beta$ (IKK- $\beta$ ), inhibiting the activation of the nuclear factor (NF)- $\kappa B$ pathway, and preventing the expression of antiviral genes (Wang et al. 2000; Gao et al. 2012). In addition, NS1 inhibits the IRF-3 transcription factor (Talon et al. 2000a) and Jun amino-terminal kinase (JNK), a kinase that phosphorylates transcription factors of the AP-1 family, increasing their activity (Ludwig et al. 2002). In addition, NS1 activates the phosphatidylinositol-3-kinase (PI3K) pathway by direct interaction with the p85 $\beta$ subunit (Hale et al. 2006), causing the phosphorylation of a downstream mediator of PI3K signal transduction, Akt. The NS1-PI3K interaction increases the rate of viral internalization, inhibits apoptosis (Ehrhardt et al. 2007) and enhances type I IFN and proinflammatory production by enhancing the activity of IRF3 (Hrincius et al. 2011; Lu et al. 2011).

IAV NS1 interacts with NLRP3, inhibiting the NLRP3 inflammasome activation, and leading to impaired IL-1 $\beta$ and IL-18 responses (Cheong et al. 2015; Moriyama et al. 2016; Park et al. 2018). In addition, NS1 inhibits host gene expression, including innate immune response genes, through different mechanisms. NS1 inhibits host pre-mRNA endonucleolytic cleavage and polyadenylation by direct interaction and inhibition of cleavage and polyadenylation specificity factor-30 subunit (CPSF30) 
D.J. Topham et al.

and the recruitment of the $\operatorname{poly}(\mathrm{A})$ polymerase to add the poly(A) tail (Nemeroff et al. 1998; Chen et al. 1999; Noah et al. 2003). Additionally, the NS1 protein can bind cellular doublestranded DNA (dsDNA), preventing loading of the transcriptional machinery to the host DNA, and thus inhibiting the expression of antiviral genes (Anastasina et al. 2016). Additionally, the NS1 of IAV binds many components of the mRNA export machinery: nuclear RNA export factor 1 (NXF1), p15, ribonucleic acid export 1 (RAE1), and adenovirus early region 1B-associated protein 5 (E1B-AP5), which interacts with both mRNAs and nucleoporins to direct mRNAs through the nuclear pore complex, blocking their function (Satterly et al. 2007). In addition to modulating innate immunity, the NS1 protein attenuates human DCs maturation and the capacity of DCs to induce T-cell responses (Fernandez-Sesma et al. 2006).

\section{IAV PA-X Protein}

IAV segment 3 encodes the PA and the PA-X proteins (Jagger et al. 2012). PA-X is translated as a +1 frameshift open reading frame (ORF), from the PA viral segment (Jagger et al. 2012), resulting in a protein with the amino-terminal 191 amino acid originating from PA and a carboxy-terminal region of 61 or 41 codons encoded by an overlapping ORF (X-ORF), which is accessed by one ribosomal frame shift in the PA gene (Shi et al. 2012).

PA-X induces the shutoff of host protein expression in infected cells, contributing to the blocking of cellular antiviral responses (Jagger et al. 2012; Hayashi et al. 2015; Hu et al. 2015, 2018; Khaperskyy and McCormick 2015; Khaperskyy et al. 2016; Levene and Gaglia 2018). PA-X selectively degrades host RNA polymerase II (Pol II)-transcribed mRNAs and noncoding RNAs in the nucleus of infected cells, thereby ensuring successful viral replication and counteracting the antiviral response in the host (Khaperskyy et al. 2016; Levene and Gaglia 2018). Complete degradation of host mRNAs following PA-X-mediated endonucleolytic cleavage is dependent on the host $5^{\prime}->3^{\prime}$-exonuclease Xrn1 (Khaperskyy et al. 2016).
The PA-X-mediated shutoff activity involves the amino-terminal endonucleolytic domain (region shared with the PA protein) (Yuan et al. 2009), resulting in the degradation of host mRNAs. Accordingly, mutations in the endonuclease active site decreases the protein's ability to induce host cellular shutoff (Hara et al. 2006; Oishi et al. 2018). Two independent studies showed that the initial 15 amino acids (positions 192-206) in the PA-X carboxy-terminal region are sufficient for the full shutoff activity of PA-X (Oishi et al. 2015; Hayashi et al. 2016). In addition, additional studies reported on the contribution of the last 20 carboxy-terminal residues in PA-X-mediated shutoff activity. Amino acids at positions 233-252 of the PA-X carboxyl terminus also strongly suppress gene expression and enhance viral replication and virulence in human pandemic H1N1 2009, avian H5N1, and avian H9N2 (Gao et al. 2015a). Simultaneously, Bavagnoli et al. (2015) also provided direct evidence that the last 20 amino acids in the PA-X carboxy-terminal region are important for endonuclease activity, and this was assumed to contribute to host shutoff by the virus. The loss of PA-X expression can increase or diminish viral replication and virulence, depending on the viral strain (Jagger et al. 2012; Gao et al. 2015b, 2015c; Hayashi et al. 2015; Hu et al. 2016; Lee et al. 2017).

\section{IAV NS1 and PA-X Protein Evolution}

These preceding studies suggest that the effect of PA-X on virus replication and pathogenesis may be host- and strain-specific, likely reflecting adaptation to a given host. IAV NS1 and PA-X proteins have the synergistic ability to inhibit host gene expression, although through different mechanisms. The NS1 protein of the highly pathogenic H5N1 influenza virus isolated from humans in 1997 did not bind CPSF30 in vitro and caused high $\beta$ interferon mRNA production and reduced virus replication. In contrast, the NS1 proteins of $\mathrm{H} 5 \mathrm{~N} 1$ viruses isolated from humans after 1998 bind CPSF30 in vitro and do not attenuate virus replication (Twu et al. 2007).

Similarly, the NS1 protein from $\mathrm{pH} 1 \mathrm{~N} 1$ 2009 isolated from humans in 2009, early after 
the pandemic began, did not bind CPSF30 and did not inhibit general gene expression (Hale et al. 2010; Clark et al. 2017b). Interestingly, the NS1 protein of currently circulating pH1N1 IAV have gained the ability to inhibit host gene expression (Clark et al. 2017b), suggesting again that inhibiting host gene expression is beneficial for the virus. Recombinant influenza pH1N1 viruses encoding NS1 and PA-X proteins that alternate in the ability inhibit host gene expression are impaired in viral growth in culture and are attenuated in vivo, compared with viruses in which only one of the viral proteins (NS1 or PA-X) inhibited host gene expression (Nogales et al. 2017c). Currently circulating viruses show increased ability to inhibit host gene expression mediated by the NS1 protein (Nogales et al. 2018a) and multiple amino acid changes in the PA-X protein that decreased PA-X-mediated inhibition of host gene expression (Nogales et al. 2018a). Balance in NS1 and PA-X activities is important for viral fitness, not only in cultured cells but also in vivo (Nogales et al. 2017c, 2018a).

\section{IAV-PB1-F2}

PB1-F2 is an accessory protein that is translated from an alternative +1 ORF of PB1 (Chen et al. 2001). PB1-F2 promotes cellular apoptosis through a mitochondrial pathway (Zamarin et al. 2005). By binding to the inner and outer mitochondrial membrane transport protein adenine nucleotide translocator 3 (ANT3) and voltage-dependent anion channel 1 (VDAC1), PB1-F2 disrupts mitochondrial integrity, releasing cytochrome $c$, and leading to apoptosis (Zamarin et al. 2005). Furthermore, PB1-F2 completely translocates into the mitochondrial inner membrane space via Tom 40 channels, and its accumulation accelerates mitochondrial fragmentation caused by reduced membrane potential $(\Delta \psi \mathrm{m})$ (Yoshizumi et al. 2014). PB1F2 variants lacking a carboxy-terminal polypeptide, often found in low pathogenic subtypes, do not affect mitochondrial function. PB1-F2-mediated attenuation of $\Delta \psi \mathrm{m}$ suppresses the RIG-I signaling pathway and activation of NLRP3 inflammasomes (Yoshizumi et al. 2014). PB1-F2 has also been shown to inhibit the RIG-ITRIM25-mediated antiviral signaling pathway by direct interaction with the mitochondrial antiviral-signaling protein (MAVS) (Varga et al. 2011, 2012). PB1-F2 promotes viral pathogenicity especially with respect to highly pathogenic viruses like the $1918 \mathrm{H} 1 \mathrm{~N} 1$ and H5N1 strains (Conenello et al. 2007; Le Goffic et al. 2011) and replication (Mazur et al. 2008).

Different mechanisms may account for the effect of PB1-F2 on promoting virus pathogenesis. Recently, it has been shown that the PB1-F2 protein of IAV 1918 pandemic virus also acquired a novel IFN antagonist function by targeting the DEAD-box helicase DDX3, a key downstream mediator in antiviral interferon signaling, toward proteasome-dependent degradation (Park et al. 2019), providing an explanation for the role of PB1-F2 in increasing virus pathogenesis. Additionally, PB1-F2 contributes to increased susceptibility to bacterial superinfection (McAuley et al. 2007). Also, PB1-F2-mediated IAV pathogenicity could result from its interaction with NLRP3, leading to inflammasome activation and increased production of $\mathrm{cy}$ tokine IL-1 $\beta$ (Zamarin et al. 2005; McAuley et al. 2013). PB1-F2 has also been shown to increase mitochondrial reactive oxygen species (ROS) and calcium $\left(\mathrm{Ca}^{2+}\right)$ efflux, which contributed to the activation of NLRP3 inflammasome (Pinar et al. 2017).

\section{IAV PB1-F2 Evolution}

A specific set of amino acid residues present in the "inflammatory motif" present within the PB1-F2 carboxyl terminus of pandemic 1968 (H3N2) IAV increases inflammation and promotes secondary bacterial pneumonia in mice (Alymova et al. 2011). Furthermore, studies indicate that enhancement of inflammation by this motif might involve activation of the NLRP3 inflammasome (McAuley et al. 2013; Pinar et al. 2017). Other carboxy-terminal PB1-F2 residues present in the "cytotoxic motif" promote development of secondary bacterial pneumonia (Alymova et al. 2014). These virulent "inflammatory and cytotoxic" motifs have been present in natural isolates from human sea- 
D.J. Topham et al.

sonal IAV of all subtypes, but there has been a trend toward a gradual reduction in the number of virulent residues over time (Alymova et al. 2018), suggesting an evolution in human hosts.

\section{IAV PB2}

The polymerase basic protein 2 (PB2), a subunit of the viral RNA polymerase complex, interacts with MAVS, and inhibits MAVS-mediated IFN$\beta$ expression (Graef et al. 2010; Iwai et al. 2010), likely because of the mitochondrial localization of certain PB2 proteins (Graef et al. 2010). The PB2 proteins of seasonal human influenza viruses localize to the mitochondria, in contrast to the PB2 proteins of avian influenza viruses. Using two recombinant human influenza viruses encoding PB2 proteins that do or do not localize to mitochondria, it was found that the virus encoding the nonmitochondrial $\mathrm{PB} 2$ protein induces higher levels of IFN- $\beta$ and, in an animal model, is attenuated compared with the virus encoding a mitochondrial PB2 (Graef et al. 2010). A mutation in the PB2 (T588I), found in swine $\mathrm{pH} 1 \mathrm{~N} 1$ viruses, but rarely detected in human pH1N1 isolates, exacerbated PB2 inhibition of MAVS-mediated IFN- $\beta$ expression, and increased the binding of PB2 to MAVS. The T588I variant induced lower levels of host IFN- $\beta$ expression than the WT strain during infection (Zhao et al. 2014).

\section{THE ROLE OF CD4 T CELLS IN PROTECTIVE IMMUNITY TO INFLUENZA}

CD4 T cells contribute importantly and in diverse ways to protective immunity to influenza. The most well-known and documented function of CD4 T cells is provision of "help" for neutralizing antibody production by $\mathrm{B}$ cells. CD4 T cells also play key functions that are distinct from delivery of help to influenza-specific B cells. First, during influenza infection, CD4 T cells are critical for the protective immunity conveyed by cytotoxic CD8 T cells; the main effector $\mathrm{T}$ cells that eliminate infected host cells in the respiratory tract (Schmidt and Varga 2018; Topham and Reilly 2018). Influenza-specific CD4 T cells that are elicited by infection are known to enhance the initial priming, expansion and establishment of long-lived memory CD8 T cells (Bevan 2004; Bedoui et al. 2016). A recent study (Ahrends et al. 2017) also provided strong evidence that CD4 T-cell help is critical for development of effector CD8 T cells that have cytotoxic potential, and for expression of cell surface molecules important for homing and extravasation, all features required for protective immunity delivered by influenza-specific CD8 T cells. At the site of infection, CD4 T cells also promote positioning of memory CD8 T cells within the infected respiratory tract (Laidlaw et al. 2014). In addition to enhancing adaptive immunity, a potentially critical function of influenza-specific CD4 T-cell memory is the ability to accelerate recruitment of innate effectors to the lung. The role of the early innate response to infection is well-documented (for review, see Iwasaki and Pillai 2014; Chen et al. 2018), and recent studies have shown influenzaspecific CD4 T memory promotes this early response and blunts virus infection (Strutt et al. 2010; Teijaro et al. 2010).

CD4 T cells also provide direct effector functions in the respiratory tract. Local production of IFN- $\gamma$ from CD4 T cells can provide direct antiviral activity in mice (Ito et al. 2011; McKinstry et al. 2012). Although influenza-specific human CD4 T cells are enriched in IFN- $\gamma$ production (Richards et al. 2018) and thus can be considered "Th1-like," in general, cytokine production in humans is highly complex (Roti et al. 2008; Purwar et al. 2011; Mosmann et al. 2014; Liechti and Roederer 2019). This complexity in humans may be caused by the multitude and diverse types of exposure of humans to influenza antigens via both infection and vaccination. Therefore, the contribution of individual CD4 $\mathrm{T}$ cell cytokines to antiviral effects in the respiratory tract in humans is not yet clear. Beyond cytokine production, an additional function of CD4 $\mathrm{T}$ cells that has been increasingly validated is cytotoxicity, which has the potential to directly eliminate influenza-infected cells (for review, see Brown et al. 2016; Juno et al. 2017; Takeuchi and Saito 2017), discussed in detail below. A final activity of influenza-specific $\mathrm{CD} 4 \mathrm{~T}$ cells is regulatory and repair function. 
These activities are contributed by diverse functional subsets of CD4 T cells, including conventional Treg, as well as IL-10- or amphiregulin-producing cells, which can diminish the damage associated with the profound inflammatory responses (Brincks et al. 2013; Arpaia et al. 2015; Zaiss et al. 2015; Egarnes and Gosselin 2018) that occurs on infection with highly pathogenic strains of influenza (Pulendran and Maddur 2015; Betakova et al. 2017; Ong et al. 2017; Wong et al. 2018).

\section{Follicular Helper Cells}

Because of the importance of neutralizing antibodies, as well as other antibody-mediated effector mechanisms (de Jong et al. 2003; Treanor and Wright 2003; Rimmelzwaan and McElhaney 2008; Neu et al. 2016; Boudreau and Alter 2019), there has been increasing emphasis on the subset of $\mathrm{CD} 4 \mathrm{~T}$ cells termed $\mathrm{T}$ follicular helper cells (Tfhs). This subset of CD4 T cells promotes the generation and maintenance of the germinal center (GC) reaction and the production of high affinity, class-switched antibody and B-cell memory. Tfhs are characterized by the expression of the chemokine receptor CXCR5, which directs localization of the primed CD4 T cells to the B-cell zone of secondary lymphoid organs. Here, Tfhs also express high levels of ICOS and PD-1 (Breitfeld et al. 2000; Schaerli et al. 2000; for reviews, see Crotty 2015; Hale and Ahmed 2015; Vinuesa et al. 2016). The transcriptional repressor Bcl-6 directs lineage commitment (Nurieva et al. 2009; Yu et al. 2009). Cytokines, including IL-6 and IL-21 (Nurieva et al. 2008), and T-cell receptor (TcR) signal strength (Fazilleau et al. 2009; Tubo et al. 2013; Keck et al. 2014; Krishnamoorthy et al. 2017) have all been shown to influence Tfh differentiation. Interestingly, beyond TcR ligand interactions and cytokine milieu, particular DC subsets may also be critical in priming of Tfhs. Lung $\mathrm{CD}_{11 \mathrm{~b}^{+}}$migratory dendritic cells $(\mathrm{cDC} 2)$ have been implicated in priming following intranasal immunization (Krishnaswamy et al. 2017), and late appearing antigen presenting cells (APCs) have been identified in the Th response following influenza virus infection (Yoo et al. 2012). In human circulation, $\mathrm{CXCR}^{+}$cells have lower expression of Bcl-6 as well ICOS and PD-1 (Chevalier et al. 2011; Locci et al. 2013; Heit et al. 2017). However, despite these phenotypic differences, circulating $\mathrm{CXCR} 5^{+} \mathrm{CD} 4 \mathrm{~T}$ cells show a superior capacity to help B cells on activation (Chevalier et al. 2011; Morita et al. 2011; Locci et al. 2013). Circulating CXCR5 ${ }^{+}$cells can be further distinguished by expression of CCR6, CXCR3, ICOS, and PD-1, with helper activity concentrated within the $\mathrm{CXCR}^{-}$cells that are $\mathrm{PD}^{+}$and/or $\mathrm{ICOS}^{+}$(Morita et al. 2011; Bentebibel et al. 2013; He et al. 2013; Locci et al. 2013; Herati et al. 2014).

There has been much recent progress in understanding the human Tfh response following influenza vaccination. Increases in Tfh-expressing activation markers $\left(\mathrm{ICOS}^{+}\right.$or $\left.\mathrm{ICOS}^{+} \mathrm{PD}^{+}\right)$ correlate with the magnitude (Bentebibel et al. 2013; He et al. 2013; Herati et al. 2014; Spensieri et al. 2016) and avidity (Bentebibel et al. 2016) of influenza-specific antibody. Circulating human Tfhs that are evident after vaccination appear to be clonally related to those within the GC and transition to a more quiescent phenotype at memory (Heit et al. 2017; Herati et al. 2017). Recent data has shown a close correlation between the elicited antibody response to vaccination and the emergence of cells in peripheral blood with markers reminiscent of follicular helper CD4 T cells (for review, see Hale and Ahmed 2015; Linterman and Hill 2016; Ueno 2016), arguing that CD4 T-cell help for vaccine responses can be tracked soon after vaccination (Herati et al. 2014). It is much more difficult to track CD4 Tfh responses in humans after infection because, first, the kinetics of responses are typically heterogeneous after diagnosis of infection and, second, many of the responding $\mathrm{CD} 4 \mathrm{~T}$ cells are recruited to the lung after infection, making sampling and quantification extremely difficult.

The antigen specificity in CD4 T-cell help is a critical parameter for antibody responses to both infection and vaccination. Recent studies in both animal models of infection (Nayak et al. 2013a; Alam et al. 2014, 2017) and human vaccination studies (Nayak et al. 2013b, 2015) suggest that the most effective help for antibody 
D.J. Topham et al.

responses occurs when the antigen specificity of the CD4 T cells matches that of the B cell. This obligate linkage likely reflects that nature of the antigen taken up by the immunoglobulin receptor, and the resulting human leukocyte antigen (HLA) class II:peptide complexes that are displayed at the cell surface of the antigenspecific B cells that recruit CD4 T-cell help in secondary lymphoid tissue. This constraint likely limits the CD4 T-cell help available in humans for novel avian strains of influenza, although recent novel vaccine constructs have described strategies to overcome this limitation (Moise et al. 2018; DiPiazza et al. 2019).

\section{Cytolytic CD4 T Cells}

There has been increasing appreciation of a distinct subset of CD4 $\mathrm{T}$ cells with cytolytic function that may also contribute to protective immunity to influenza. In many respects, cytotoxic CD4 T cells resemble CD8 T cells in terms of key transcriptional regulators (Takeuchi et al. 2016) and efficiency of killing (Hildemann et al. 2013) and in primary cytotoxic mechanisms involving perforin and granzymes (Brown et al. 2016; Takeuchi and Saito 2017). Both IL-2 and inflammatory signals, abundant in responses to viral infections, are thought to be central elements that promote the cytolytic potential of CD4 T cells (Hua et al. 2013; Workman et al. 2014). Recent studies in human peripheral blood CD4 T cells have identified the transcription factor HOBIT (homolog of Blimp-1 in T cells) as a unique identifier of cells expressing granzymes, perforin and other markers linked to cytolytic function (Oja et al. 2017). Until recently, CD4 T cells with cytotoxic function have been quantified by expression of stored cytolytic mediators, such as granzyme, requiring that cells be permeabilized before analyses. However, recently, cell surface markers, such as CRTAM (class I-restricted $\mathrm{T}$ cell-associated molecule) (Takeuchi et al. 2016) and the natural killer cell marker NKG2C/E (Marshall et al. 2017) have been defined that have the potential to quantify and permit isolation of intact cells with cytotoxic potential. The role of cytolytic CD4 $\mathrm{T}$ cells in influenza immunity has been supported by the prominence of this phenotype in the infected lung (Workman et al. 2014; Brown et al. 2016; Marshall et al. 2017) and has been found as correlate of protection in human challenge studies (Wilkinson et al. 2012).

One intriguing unresolved question is whether cytolytic CD4 T cells perform a unique function that is distinct from cytotoxic CD8 T cells. Because of their similarity in function and development, why does the host need the apparent redundant mechanism for cell-mediated cytotoxicity? Two possible non-mutually exclusive possibilities can be envisioned. Cytotoxic CD4 $\mathrm{T}$ cells may serve as a complementary mechanism, eliminating infected cells at selected sites within the lung, perhaps controlled by a unique array of lung positioning molecules (Richter et al. 2007; Takamura 2017). Recent studies have revealed the diversity of infected and antigen-bearing cells detectable in the lung early after infection (DiPiazza et al. 2017) that may be located at distinct sites in the respiratory tract. In addition, studies of lung tissue by microscopy have indicated that CD4 and CD8 T cells localize to different subregions in the lung (for review, see Szabo et al. 2019). Alternatively or additionally, CD4 T cells may be serve as a fail-safe mechanism when CD8 T cell epitopes are lost from circulating influenza strains (Voeten et al. 2000), which may be less likely to occur in influenza-specific CD4 T-cell repertoire because of their broader epitope specificity (for review, see Sant et al. 2018a).

\section{Abundance and Specificity of Human Influenza-Specific CD4 T Cells}

Recent efforts have sought to quantify and characterize the repertoire of circulating influenza-specific CD4 T cells from human subjects (Assarsson et al. 2008; Babon et al. 2009; Richards et al. 2010, 2015; Wilkinson et al. 2012; Chen et al. 2014; Savic et al. 2016; Uchtenhagen et al. 2016). In general, these studies have found that in most healthy adults, there are detectable influenza-specific CD4 $\mathrm{T}$ cells, but that the abundance is highly variable (Assarsson et al. 2008; Wilkinson et al. 2012; Hayward et al. 2015; Richards et al. 2015; Savic et al. 2016). 
With the increased interest in the design of universal influenza vaccines (Krammer and Palese 2015; Paules et al. 2017), there has been particular interest in candidate epitopes that would elicit broadly cross-reactive CD4 T cells that detect genetically conserved peptide epitopes reactive shared among diverse viral strains (Eliasson et al. 2018; Lee et al. 2018; Tutykhina et al. 2018). In healthy adults, there is prominent CD4 T-cell reactivity toward epitopes from the internal virion M1, NP (Wilkinson et al. 2012; Chen et al. 2014; Hayward et al. 2015; Savic et al. 2016), and polymerase (Assarsson et al. 2008; Richards et al. 2010) proteins. HA-reactive CD4 T cells have also been reported to be abundant in the memory compartment of many individuals (Babon et al. 2009; Richards et al. 2010, 2015; Hayward et al. 2015; Leddon et al. 2015), and these may be particularly important for provision of help for neutralizing antibody responses (Sant and McMichael 2012; Nayak et al. 2013b, 2015; Alam et al. 2014, 2017). In humans, reactivity to HA is enriched for specificities in the more highly conserved HA2 domain (Richards et al.2015), allowing candidate epitopes in this region to be used in universal vaccine efforts. CD4 T cells specific for M1, NP, polymerase proteins, and highly conserved regions of HA are likely to be the major specificities elicited in response to infection with heterologous or novel potentially pandemic strains (Roti et al. 2008; Babon et al. 2009; Richards et al. 2009; Duvvuri et al. 2010; Alam and Sant 2011; Weinfurter et al. 2011; Bethell et al. 2013; Duvvuri et al. 2013) and may contribute to attenuating the course of infection. The degree of cross reactivity in CD4 T cells elicited in response to the novel 2009 potentially pandemic strain is likely to have contributed to the mild course of disease observed in many subjects, despite a lack of cross-reactive neutralizing antibody.

A Major Challenge: Identification of the CD4 T-Cell Subset(s) That Are a Limiting Factor for Human Protective Immunity to Influenza Virus

It is clear that the presence of high-affinity neutralizing antibody to influenza is the best correlate of protection from natural infection.
However, the ability of influenza virus to mutate and to deviate from serum-mediated protection and the resulting high burden of seasonal influenza infection indicates that current strategies to induce sterilizing immunity are inadequate. Thus, there is a need to enhance protective immunity by more effectively engaging the cellular arm of the immune response. Despite this need, a significant challenge is defining which $\mathrm{CD} 4$ $\mathrm{T}$ cells are deficient and need boosting by vaccination. In studies of human immunity to influenza, one of the most difficult issues is identification of cells that will participate in the response to infection or vaccination. For example, the vast majority of studies that have identified correlates of influenza-specific CD4 T cells with the elicited antibody responses have performed so only through examination of cells that have increased their representation after vaccination (Bentebibel et al. 2013; Nayak et al. 2013b, 2015; Spensieri et al. 2013, 2016; Herati et al. 2014; Koutsakos et al. 2018). Very few correlates have been identified within the circulating CD4 T-cell repertoire before vaccination or infection. One human influenza challenge study did correlate levels of preexisting cytotoxic CD4 $\mathrm{T}$ cells with protection, but this subset was identified after in vitro expansion (Wilkinson et al. 2012). More sensitive detection of additional markers such as chemokine receptors expressed by influenza-specific CD4 T cells, coupled with early sampling times (e.g., 1-3 d postvaccination or -infection) and human challenge studies (Lillie et al. 2012; Oxford 2013; Darton et al. 2015; Pleguezuelos et al. 2015) would likely provide insight into the circulating memory $\mathrm{CD} 4$ T-cell subsets that are recruited into the response and whose presence in peripheral blood of humans either positively or negatively correlates with protective immunity to influenza. As knowledge is gained in these issues, we will have more of the needed insight into the most critical deficiencies in the influenza-specific CD4 T-cell repertoire and, with this, the needed framework for improved vaccine strategies. Studies in both animal models and more recent studies in humans have provided evidence that influenzaspecific $\mathrm{T}$ cells can establish long-term tissue resident memory (Zens et al. 2016, 2017; Oja 
D.J. Topham et al.

et al. 2018; Chu et al. 2019; Snyder et al. 2019) that may provide protective immunity very early after infection.

In considering what subsets of CD4 $\mathrm{T}$ cells are most critical to protection from influenza in humans, it is important to understand that many of the in vivo studies that have implicated particular effector functions of CD4 T cells to protection from influenza challenge have used animal models. In these studies, the contribution of CD4 T cells to immunity has been shown either using adoptive transfer strategies to introduce a CD4 $\mathrm{T}$ cell with dominant function into a naive host or where functionality of the CD4 T cells can be eliminated or promoted by genetic means (Teijaro et al. 2011; Brown et al. 2012; McKinstry et al. 2012). Extrapolating these studies to humans is difficult because of the tremendously complex preexisting immunity to influenza that accumulates in humans over a lifetime of exposure via infection and vaccination. To be able to understand the contribution of CD4 T cells in humans toward protective immunity or more robust responses to vaccination, it is essential to quantify the functional activities of CD4 T cells that are limiting or that constitute bottlenecks in protective immunity to influenza: Do most people need more cytotoxic CD4 T cells or more tissue resident memory? Is CD4 T-cell help for rapid antibody responses to infection limiting for most people? Do only a small number of influenza-specific CD4 T cells in humans have the capacity to be recruited to the lung early after infection and quickly mobilize the innate response? Does initial contact of the human host to influenza via peripheral vaccination rather than infection or intranasal vaccination diminish establishment of memory CD4 T cells that can be recalled into the lung after infection or that will establish long-term tissue resident memory (Zens et al. 2016; Calzas and Chevalier 2019; Jansen et al. 2019; Liu et al. 2019). Addressing these issues in humans is difficult because of the challenges associated with sampling of the respiratory tract after infection, but these are critically important issues to gain better insight into. A more comprehensive understanding of these issues will help direct the priorities in design and composition of more effective vaccines that most effectively establish protective immunity.

From the studies of human responses to vaccination and animal models of infection, it is clear that CD4 T cells of the correct functional subset (Bentebibel et al. 2013, 2016; He et al. 2013; Spensieri et al. 2016) and specificity (Nayak et al. 2013a,b; Alam et al. 2014, 2017; He et al. 2017) can be a limiting factor in eliciting neutralizing antibody. Evidence from animal models has supported the possibility that more abundant CD4 $\mathrm{T}$ cells of the correct specificity can enhance antibody production during the course of infection (Alam et al. 2014). Such early antibody responses, even of nonneutralizing HA or NA specificities, could blunt the course of infection, through cellular and Fcreceptor-based mechanisms (Wohlbold et al. 2015, 2017; DiLillo et al. 2016; Tan et al. 2016; He et al. 2017; Sicca et al. 2018; Boudreau and Alter 2019). Vaccine strategies that populate the host with CD4 $\mathrm{T}$ cells that are poised to become Tfh cells of the desired protein specificity, matching the B-cell specificity, may thus lead to antibody responses that can lead to either sterilizing immunity and/or attenuated disease. Greater peripheral Tfhs following adjuvanted vaccination (Mastelic Gavillet et al. 2015; Harandi 2018), use of high-dose influenza vaccination in the elderly (Pilkinton et al. 2017), and strategies that target protein vaccines to cell surface proteins such as Clec9a (Kato et al. 2015) or particular DC subsets (Yamasaki et al. 2016) suggest that it may be possible to use alternative vaccination strategies to optimize Tfh priming, which may foster stable Tfh memory that can promote future protective antibody responses.

The possibility of enhancing protection from influenza infection through amplification of $\mathrm{T}$-cell responses has been supported by recent vaccine and challenge studies in humans (Lillie et al. 2012; Pleguezuelos et al. 2015). Use of virus vectors to expand $\mathrm{T}$ cells specific for M1 and NP, without elicitation of antibodies, was associated with a lower infection frequency, virus shedding, and diminished symptomology when a challenge virus was administered (Lillie et al. 2012). Consistent findings were observed when multi-epitope vaccines were similarly tested 
(Pleguezuelos et al. 2015). It is likely that these types of experimental challenge models (Oxford 2013; Darton et al. 2015), coupled with strategies to selectively promote expansion of CD4 T cells with the desired functionality and specificity, could provide critical new insight into the most limiting protective functions of CD4 T cells.

Collectively, recent advances have provided much of the insight needed to initiate cross protective immunity at the systemic level, as well as the site of influenza infection. The control of CD4 T-cell fate decisions that regulate generation and expansion of discreet functional subsets of CD4 $\mathrm{T}$ cells that can contribute to protective immunity to influenza in humans are complex and multilayered. The major challenge will be to design the appropriate vaccination and challenge studies to reveal and ultimately correct the most critical deficits in CD4 T-cell functions in human populations. The roles of specific viral antigens as targets of vaccination, different innate activators, and antigen persistence are increasingly better understood (Bautista et al. 2016; Zens et al. 2016; Allie and Randall 2017; Nish et al. 2017; Strutt et al. 2017), which can also better inform vaccine designs that populate the host with the most broadly protective CD4 T cells.

\section{B-CELL RESPONSE TO SEASONAL INFLUENZA INFECTION}

The B-cell response to IAV infection has recently been comprehensively reviewed (Krammer 2019) and is also discussed extensively in this volume by Wilson and colleagues (Wilson et al. 2019). Here, we emphasize the role of $\mathrm{MBCs}$ in the B-cell response to seasonal IAV infection in influenza-immune adults (Sangster et al. 2019). All proteins expressed by an infecting IAV can potentially activate $B$ cells and generate specific antibodies (Abs) and MBCs, but the response is typically strongest against the more abundant structural proteins. Circulating Abs generated by IAV infection can be maintained for long periods. Long-term maintenance of circulating virus-specific IgG levels primarily reflects seeding of the bone marrow by activated precursor cells that give rise to long-lived plasma cell populations (Halliley et al. 2015; Lau et al. 2017). Infection also generates IgA antibodysecreting cells (ASCs) that migrate to the submucosa of the respiratory tract and maintain a protective IgA barrier at mucosal surfaces (Kato et al. 2013). Abs against the virus's surface glycoproteins, the HA and NA, have direct antiviral activity and provide the most effective protection against the initiation or progression of infection. Most Abs generated by infection are likely to target the viral HA, the viral attachment protein that initiates cell infection by binding to sialylated receptors.

Molecular features of the HA are important determinants of the fine specificity and function of anti-HA Abs. The HA consists of two structurally distinct domains: an antigenically variable membrane-distal head domain containing the receptor binding site and a relatively conserved membrane-proximal stalk domain $(\mathrm{Wu}$ and Wilson 2018). The head domain is immunodominant over the stalk domain and is the target of the vast bulk of HA-reactive Abs produced by IAV infection (Zost et al. 2019). Abs against the HA head that block binding of virus to host cells have the most potent virus neutralizing activity; Abs against the stalk protect via other mechanisms and are less potently neutralizing, but are more broadly reactive across HA variants and subtypes (Krammer and Palese 2013). Modification of antigenic sites in the head domain by antigenic drift generates variant influenza strains that are less well controlled by previously formed anti-HA Abs. Periodically, HA variant viruses emerge and cause influenza outbreaks in communities in which diminished protection by preexisting Abs is widespread (Petrova and Russell 2018).

Abs against the HA are also the basis of "original antigenic sin" (OAS) as originally termed (Francis 1960) and more recently designated "antigenic seniority" (Lessler et al. 2012). Based on Ab titers measured by hemagglutination inhibition assay, influenza infection of adults typically generates an $\mathrm{Ab}$ response that is broadly cross-reactive. Frequently, this response is of the OAS type and characterized by preferential boosting of Abs against sets of HAs 
D.J. Topham et al.

related to those of viruses that circulated early in an individual's life (Fonville et al. 2014; Tesini et al. 2019). The term OAS has also been applied to circulating HA-reactive $\mathrm{Ab}$ levels that are highest against "older" HAs, a pattern that is largely maintained by OAS responses to IAV infection. It is postulated that OAS reflects a pattern of expansion of HA-reactive MBCs "imprinted" by early-life HA exposure, probably in the form of significant IAV infection (Cobey and Hensley 2017; Henry et al. 2018).

If infection is not blocked or quickly terminated by preexisting Abs, perhaps because of waning levels or the emergence of an "escape" variant, the activation of MBCs results in rapid and vigorous secondary $\mathrm{Ab}$ production that acts in concert with other forms of adaptive responses to clear infectious virus (Inoue et al. 2018). Typically, MBCs are the isotype-switched products of GC reactions in which they have undergone somatic hypermutation and selection for expression of B-cell receptors (BCRs) with high affinity for the activating antigen. After formation, MBCs generally disperse to lymphoid tissues throughout the body. However, MBCs generated by IAV infection are likely to maintain highest frequencies at sites of formation in the respiratory tract (Pichyangkul et al. 2015; Jegaskanda et al. 2018; Koutsakos et al. 2018). MBCs are more readily activated than naive $B$ cells because of cell-intrinsic factors that include epigenetic modifications, altered transcriptional networks, and greater signaling capacity of the IgG BCR (Good-Jacobson 2018). Furthermore, MBCs localize around the periphery of lymphoid tissues and are better positioned to capture antigen draining from a site of infection than are B-cell follicle-associated naive $\mathrm{B}$ cells (Aiba et al. 2010; Moran et al. 2018; Zhao et al. 2018). Antigen uptake is the first step in establishing cognate interactions with CD4 T cells that are essential for MBC (and naive B cell) activation (Cyster and Allen 2019). In many cases, it is likely that the strong $\mathrm{Ab}$ response generated by $\mathrm{MBC}$ activation after infection is sufficient to terminate infection with little, if any, contribution by naive B cells.

Evidence that early production of antiviral Abs following IAV infection in immune adults results from activation of preexisting MBCs comes from analysis of Ab-secreting plasmablasts (PBs) that appear in the circulation at about the same time as the first virus-induced Abs. These PBs generally reach peak frequencies 4-6 d post-symptom onset, but remain detectable for another 1-2 wk (Tesini et al. 2019). Notably, up to $50 \%$ of virus-specific PBs bind the viral HA. Analysis of HA-reactive PBs has identified recently proliferated clonal lineages that express Abs with highly mutated immunoglobulin variable genes, indicating derivation from recently activated MBCs that had previously undergone affinity maturation (Wrammert et al. 2011).

In responding lymph nodes, $\mathrm{MBC}$ activation that produces the first Abs (and circulating PBs) following IAV infection occurs extrafollicularly in the outer lymph node cortex (Moran et al. 2018). It is unclear whether MBCs are also generated via this extra-GC pathway or whether $\mathrm{MBCs}$ are only generated in GCs after some level of remodeling of antigen reactivity. Notably, the recent analysis by Tesini et al. (2019) showed a close relationship between patterns of early $\mathrm{Ab}$ production after IAV infection measured against a range of HA variants (including OAS patterns) and patterns of early expansion of MBC populations reactive to the same set of HAs. This result is consistent with $\mathrm{Ab}$ production and MBC formation stemming from activation of the same precursor MBC. B-cell clonal lineage analysis by Ellebedy et al. (2016) also indicated that $\mathrm{PB}$ and $\mathrm{MBC}$ lineages could have originated from the same activated $\mathrm{MBC}$, but does not exclude a contribution of GCs to at least part of the $\mathrm{MBC}$ lineage.

It is generally accepted that OAS patterns of $\mathrm{HA}$-reactive $\mathrm{Ab}$ production after IAV infection reflect the competitive dominance of MBCs reactive to conserved epitopes on the HA head domain (Cobey and Hensley 2017; Henry et al. 2018). The reactivity profiles of Abs expressed by individual PBs generated early in the response to IAV infection have not been extensively characterized. However, limited studies indicate that at least some of the $\mathrm{PB}$-expressed Abs bind to one or more older HAs, sometimes with higher affinity than to the infecting virus 
HA (Moody et al. 2011; Wrammert et al. 2011). These findings are consistent with PB derivation from MBCs that were generated by exposure to older HAs and respond to sufficiently conserved epitopes on the HA of the infecting virus. Highaffinity MBCs would be expected to outcompete lower affinity MBCs for available antigen and thus obtain the strong level of T-cell help associated with differentiation of activated $\mathrm{B}$ cells into Ab-secreting PBs. However, the importance of MBC affinity might be diminished in the context of IAV infection, which is associated with increased levels of cytokines and TLR agonists that help drive B-cell activation (Lam and Baumgarth 2019).

In addition to the broad HA head-reactive $\mathrm{Ab}$ response, $\sim 10 \%-20 \%$ of anti-HA Abs generated by seasonal IAV infection bind to the stalk domain. The response to the stalk follows the same kinetics as the antihead response and includes early induction of stalk-specific PBs with high numbers of mutations in immunoglobulin variable genes, indicating formation from activated MBCs (Wrammert et al. 2011; Margine et al. 2013; Tesini et al. 2019). A key determinant of the magnitude of the $A b$ response to the stalk is the dominance of head-reactive over stalk-reactive MBCs in competition for antigen. An individual's exposure to HA through vaccination and infection would be expected to progressively increase the ratio of head- versus stalk-reactive MBCs, primarily because of immunodominance of the head. Notably, few stalk-reactive Abs are produced after seasonal inactivated influenza vaccination (Moody et al. 2011; Wrammert et al. 2011), suggesting that factors associated with IAV infection facilitate stalk-reactive $\mathrm{MBC}$ activation.

A subset of B cells activated by IAV infection enter GC reactions in which they undergo affinity maturation (Mesin et al. 2016). A proportion of the preexisting MBCs activated by infection become GC B cells as an alternative to extra-GC differentiation into PBs. Activated naive B cells might also enter GCs, especially when infection is severe and the response is prolonged (Wrammert et al. 2011). Experiments in mice indicate that GCs initially generate mostly MBCs and then switch after 2 or more weeks to plasma cell formation (Weisel et al. 2016). MBC formation after fewer rounds of selection would limit the extent of affinity maturation or "adaptation" to the HA of the infecting virus, but might provide the advantage of expanding MBCs able to respond to the infecting virus $\mathrm{HA}$ as well as to emerging HA variants. There is nevertheless a degree of affinity maturation of de novo-generated MBCs. Tesini et al. (2019) analyzed responses to seasonal H3N2 infection in the 2012-2013 season when infecting viruses were HA drift variants (DeDiego et al. 2016a). Circulating MBCs adapted to the $\mathrm{H} 3$ head domain were detected within $\sim 4$ wk of symptom onset. Evidence that HA-reactive MBCs with increased levels of somatic hypermutation are formed many months after HA vaccination in humans indicates that affinity maturation of MBCs continues long after any early switch by GCs to predominantly plasma cell production (Andrews et al. 2019; Matsuda et al. 2019).

In summary, a critical determinant of the $\mathrm{B}$-cell response to seasonal IAV infection in immune adults is the responsive MBC pool generated by infection and vaccination over many years. The composition of an individual's HA-reactive MBC pool in particular reflects the imprint of early-life HA exposure and is responsible for OAS patterns of Ab production. Early PB formation from activated high-affinity MBCs optimizes the protective efficacy of the initial wave of Abs. Competition for antigen between MBCs is a key determinant of the specificities of MBCs that receive activation and differentiation signals. The outcome of $\mathrm{MBC}$ competition depends on the numbers and affinities of specific MBCs, immunodominance features of particular IAV proteins, and the forms of antigens available for recognition by $B$ cells. Intramolecular competition between HA-reactive MBCs is the basis for OAS response patterns, as well as the strength of responses to the HA head versus the stalk. Intermolecular competition, as might occur when proteins are present on intact virions or envelope fragments, could determine the strength of early $\mathrm{Ab}$ responses to the HA versus the NA. Activated preexisting MBCs form not only PBs, but also generate cells that, along with activated naive B cells, seed GCs 
D.J. Topham et al.

for generation of MBCs and long-lived plasma cells adapted to variant IAV proteins. As part of the B-cell response, MBCs that maintain OAS responses are replenished, perhaps via both extra-GC and GC pathways. Our increasing understanding of B-cell response processes continue to guide development of vaccine formulations and administration strategies that optimize protective efficacy.

\section{$\mathrm{CD8}^{+}{ }^{\mathrm{T}}$-CELL RESPONSES TO SEASONAL INFLUENZA INFECTION}

The human immune system is exposed to influenza in most people during their childhood. Until recently, fewer children were vaccinated, suggesting these early exposures are most likely to be from infections. The field has also recently realized that these early life exposures result in lifelong "imprinting" of the immune system, particularly in regard to antibody and memory B-cell specificities (for review, see Guthmiller and Wilson 2018; Lewnard and Cobey 2018; Francis et al. 2019; Sangster et al. 2019). The early infections also generate long-lived memory $\mathrm{T}$ cells, although whether a pattern of antigenic imprinting is created has not yet been shown.

In recent decades, much insight has been gained on the elicitation of CD8 T cells in the response to influenza, most of which is derived from animal models of infection. The CD8 Tcell response to influenza begins $\sim 2-3 \mathrm{~d}$ after a primary infection, when virus antigen-bearing, activated DCs arrive in the lymph nodes draining the site(s) of infection, which are typically the nasopharynx, trachea, and upper airways in the case of seasonal influenza viruses (Legge and Braciale 2003; Belz et al. 2004; Yoon et al. 2007). Specialized APCs that carry influenza antigens from the lung to the draining lymph nodes are derived from $\mathrm{CD}_{103}{ }^{+}$DCs that patrol the respiratory epithelium (Ho et al. 2011; Beauchamp et al. 2012). Naive CD8 T cells specific for peptides derived from viral proteins encounter these professional APC or that access viral antigens via cross presentation (den Haan and Bevan 2001; Di Pucchio et al. 2008). After processing the protein antigens of the virus into short peptides, APCs display these peptides on their sur- face in the context of self-derived class I histocompatibility leukocyte antigens (HLA). Naive $\mathrm{T}$ cells preferentially migrate through secondary lymphoid organs (SLOs) such as lymph node and spleen where they encounter antigen-bearing DCs. Naive T cells are efficient in trafficking to SLOs by expressing adhesion molecules (L-selectin/CD62L) and chemokine receptors (CCR7) responsive to ligands expressed on high endothelial venules (HEVs) supplying blood to SLOs (Sallusto et al. 1999; Geginat et al. 2001). During the 1-3 d within the draining lymph node, the CD8 T cells receive signals through their TCR and costimulatory molecules, CD28 on the T cells, and CD80 and CD86 expressed by the activated DC. Additional stimulatory signals include cytokines like IL2, released in autocrine and paracrine fashions, the latter likely from activated virus-specific $\mathrm{CD}^{+}{ }^{+} \mathrm{T}$ cells interacting with the same or adjacent DC. These signals drive proliferation and differentiation of the naive $\mathrm{CD}^{+} \mathrm{T}$ cells into activated effector $\mathrm{T}$ cells and memory cells. It is worth noting that the lymph nodes may not be the only SLOs in which effector $\mathrm{T}$ cells are generated. Mathematical modeling suggested the lymph nodes cannot numerically account for the number of effector $\mathrm{T}$ cells found in the lung during experimental infection of mice with influenza (Wu et al. 2011). Later experimental confirmation showed that the spleen is a major source of effector $\mathrm{CD}^{+} \mathrm{T}$ cells specific for influenza (Turner et al. 2013), although this may depend on the virus strain (Keating et al. 2018). Splenic priming may occur because activated DC from the site(s) of infection enter circulation and migrate to the spleen or because some of the abundant viral antigens in the lung drains to the spleen. Within the SLOs, the elicited CD8 T cells down-regulate SLO homing receptors and begin expressing molecules that further antagonize retention in the SLOs. Instead, they acquire expression of adhesion molecules like CD44 and increased LFA-1 and CD49d integrins before leaving the SLOs and entering the bloodstream (Siegelman et al. 2000). LFA-1 and CD49d recognize coreceptors up-regulated by the innate response on blood vessels within inflamed tissues such as infected mucosal surfaces (Siegel- 
man et al. 2000). These interactions along with chemokine signals on the endothelium cause the $\mathrm{T}$ cells to arrest and undergo transendothelial migration into the infected tissue. CD8 T cells migrate through the space between the blood vessel and airway epithelium and cross the basement membrane of the epithelium to reach the infected epithelial cells (Lambert Emo et al. 2016). Mouse studies suggest the CD8 $\mathrm{T}$ cells must also have an encounter with APC within the tissue to be retained and exert effector functions (McGill et al. 2008).

\section{Role of CD8 T Cells in Protection}

$\mathrm{CD}^{+} \mathrm{T}$ cells recognize peptides 9-10 amino acids in length (called an "epitope") presented in the context of HLA class I molecules on the surface of APCs and infected cells (Krangel et al. 1982; Parham 1988). Many of the dominant epitopes identified thus far come from viral proteins that are relatively conserved, such as the internal proteins. CD8 T cells can even recognize epitopes derived from different strains of influenza within the same lineage (e.g., influenza A H1N1 and H3N2), but also across lineages (influenza A, B, or C) (Koutsakos et al. 2019), although these highly cross-lineage-reactive cells are rare. The genetic conservation of CD8 T-cell peptide epitopes makes this subset of $\mathrm{T}$ cells attractive candidates for targets of universal flu vaccines that provide broad cross-reactive immunity, also termed heterologous immunity (Bennink et al. 1978). Unlike neutralizing antibodies, this type of immunity does not prevent infection but serves to reduce the severity, magnitude, and duration of the infection (Bennink et al. 1978; Ray et al. 2004). Two studies of natural infection or deliberate challenge of humans with influenza came to different conclusions regarding the type of $\mathrm{T}$ cells that reduce disease severity. In the study of natural infection with the $2009 \mathrm{H} 1 \mathrm{~N} 1$ virus, subjects with higher frequencies of $\mathrm{CD}^{+} \mathrm{CD}^{+} 5 \mathrm{RA}^{+} \mathrm{CCR}^{-}$effector memory $\mathrm{T}$ cells making IFN- $\gamma$ and having cytotoxic potential associated with reduced disease (Sridhar et al. 2013). These subjects were seronegative before infection and there was no correlation with $\mathrm{CD} 4 \mathrm{~T}$-cell responses. In a model of human influenza challenge using either $\mathrm{H} 1 \mathrm{~N} 1$ or $\mathrm{H} 3 \mathrm{~N} 2$ viruses, the investigators found an inverse correlation between disease severity and $\mathrm{CD}^{+}$memory $\mathrm{T}$-cell frequencies before infection (Wilkinson et al. 2012). The reasons for the discrepancy in the conclusions are not clear, but they were very different study designs. In a much earlier classical study performed by McMichael et al. (1983), the frequencies of preexisting cytotoxic cells correlated with reduced disease. Wang and colleagues (2015) found that H7N9 avian influenza-infected subjects who recovered early from infection had higher frequencies of virus-specific $\mathrm{CD} 8^{+}$ $\mathrm{T}$ cells that produced IFN- $\gamma$ relative to those individuals with longer duration illness or death.

Recent evidence suggests that local T-cell immunity in the respiratory tract may be a particularly effective form of preexisting $\mathrm{T}$ cell in the host (Cauley 2016; Takamura 2018; Topham and Reilly 2018). Memory $\mathrm{CD}^{+} \mathrm{T}$ cells that reside in the airway tissues for long periods are called tissue resident memory (Ray et al. 2004) or $T_{R M}$ cells. $T_{R M}$ cells express adhesion molecules that allow them to interact with the extracellular matrix (CD49a/ $\alpha-1$ integrin) and epithelial cells directly (CD103/o-e) and are found in both mice and humans (Piet et al. 2011; Purwar et al. 2011). They can be found in all tissues, but preferentially within barrier tissues such as the respiratory tract, digestive tract, and reproductive tract and skin (Kumar et al. 2017; Rosato et al. 2017). $\mathrm{T}_{\mathrm{RM}}$ cells are believed to perform constant surveillance and are unusually effective at providing rapid protection presumably because they are already located at the site of infection (Cauley 2016). They act immediately upon encounter with infected cells during the first few days of the secondary infection, before reactivated memory $\mathrm{T}$ cells from SLO reach the tissue, which can take 3-5 d (Woodland et al. 2002; Swain et al. 2004). In a mouse study, the secondary challenge of influenza infection primed mice that lacked lung $\mathrm{T}_{\mathrm{RM}}$ cells because of antibody blocking or genetic deletion of a key integrin $(\mathrm{CD} 49 \mathrm{a} / \alpha-1)$ that reduced $\mathrm{T}_{\mathrm{RM}}$ cells led to increased mortality and increased disease (Ray et al. 2004). 
D.J. Topham et al.

\section{Specificity of CD8 T Cells}

Studies of $\mathrm{CD}^{+}$T-cell antigen specificity in adult humans have shown broad reactivity across the influenza proteome, with a high degree of variability in both frequency and specificity across all HLA types (Rimmelzwaan et al. 2009; Quinones-Parra et al. 2014; Grant et al. 2016; Li et al. 2019). In a study looking for cross reactive $\mathrm{CD} 8 \mathrm{~T}$ cells against an $\mathrm{H} 5 \mathrm{~N} 1$ virus, with cohorts in both Asia and Europe, the influenza proteins with the most cross-reactivity were the matrix protein (MP), nucleoprotein (NP), and polymerase basic subunit 1 (PB1) of the virus, although $\mathrm{T}$ cells specific for epitopes from all virus proteins were detected (Lee et al. 2008). The reasons for the relative focus on MP, PB1, and NP are not clear, though it may be the conservation, relative abundance of these proteins after infection, or preferential processing in the APC. There is even evidence of cross-recognition of relatively conserved NP peptides (NP388-346 and NP44-52 restricted by HLA B27 and $A^{*} 01: 01$, respectively) even though there are point mutations in those epitopes in some viruses (Grant et al. 2018). The same group identified conserved epitopes across influenza $\mathrm{A}, \mathrm{B}$, and $\mathrm{C}$ viruses, potentially providing strategies for developing universal vaccines (Koutsakos et al. 2019). It is important to define shared epitope specificities to successfully design vaccines that promote cross-reactive immunity. Repeated exposures to influenza during one's lifetime may reinforce particular specificities for more conserved epitopes (Van BraeckelBudimir et al. 2017, 2018).

\section{Effector Mechanisms of CD8 T Cells}

In contrast to $\mathrm{CD} 4 \mathrm{~T}$ cells, $\mathrm{CD} 8{ }^{+} \mathrm{T}$ cells memory subsets are far less diverse. T cytotoxic 1 (Tc1) and $\mathrm{T}$ cytotoxic 2 (Tc2) cells defined by the ability to make IFN- $\gamma$ or IL4, respectively, have been described. Tc 2 cells are rare and have been most frequently studied and observed in experimental mice, in a cancer setting or in vitro (Dobrzanski et al. 2004). By far, human CD8 ${ }^{+}$ $T$ cells specific for influenza are most commonly cytotoxic, and make IL2, IFN- $\gamma$, and/or TNF- $\alpha$ in different combinations (La Gruta and Turner 2014). Studies in mice have indicated that cytotoxicity is due to the targeted secretion of perforin and granzymes to infected cells, although less well-targeted cell death pathways such as Fas/Fas ligand (Topham et al. 1997) and TRAIL (Brincks et al. 2008) have been implicated in augmenting cytotoxicity. Studies involving HIV or CMV (Betts et al. 2006; Kannanganat et al. 2007) infected subjects suggested the cells that produce multiple cytokines (IL2, IFN- $\gamma$, and TNF- $\alpha$ ) are the most potent effectors, correlating with decreased viral load. Whether the same is true in influenza is not well-established.

\section{Age}

Age has a strong influence on $\mathrm{T}$-cell responses to influenza. Of course, during infancy, influenza infection is confronted by a naive immune system with no preexisting T-cell or B-cell adaptive immunity to the virus. However, recent work has shown that infants possess a unique nonconventional population of $\mathrm{CD}^{+}{ }^{+} \mathrm{T}$ cells at birth that express CD31 and secrete IL8 upon TCR and CD28 costimulation (Scheible et al. 2015, 2018). Furthermore, the frequencies of these $\mathrm{CD} 1^{+} \mathrm{CD}^{+}$naive $\mathrm{T}$ cells at discharge from the hospital positively correlate with reduced frequency of respiratory virus infections, and reduced severity when infected, during the first year of life (Scheible et al. 2018). This was true for all the respiratory pathogens tested. The mechanism of protection in the respiratory tract is not known, but unlike $\mathrm{T}$ cells from older children and adults, these $\mathrm{T}$ cells respond to Tolllike receptor ligands (Kollmann et al. 2009) and may have dual lymphatic and mucosal homing capacity. They express CD62L and the $\alpha-4 / \beta-7$ heterodimer that in older children and adults direct activated and memory $\mathrm{T}$ cells to mucosal sites, and the gut in particular. Interestingly, the neonatal lung expresses the coreceptor mucosal addressin cell adhesion molecule (MAdCAM) (Salmi et al. 2001). This homing molecule may convey the potential to migrate directly into the airway tissues, although this remains to be confirmed. The $\mathrm{CD} 31^{+} \mathrm{CD} 8^{+} \mathrm{T}$ cells disappear over the first year of life, and MAdCAM expression in 
the lung is also reduced (Scheible et al. 2018). Together, these suggest there is a mechanism to provide protective immunity to respiratory pathogens during infancy, giving time for adaptive immune responses to develop.

The other end of the spectrum, in old age, also affects $\mathrm{CD}^{+} \mathrm{T}$-cell responses to influenza. The elderly are generally considered to be less immunologically competent in many aspects of their immune compartments (Gustafson et al. 2018; Lorenzo et al. 2018; Crooke et al. 2019). This feature of aging is most apparent in the Bcell and immunoglobulin responses to vaccination (Henry et al. 2019). Part of the deficiency is reduced diversity in the B-cell repertoire, as well as lower degrees of affinity maturation, which together affect the ability to respond to new or drifted antigens. The $\mathrm{CD} 8^{+} \mathrm{T}$-cell repertoire is also known to become less diverse and more restricted with age. For example, in an analysis of TCR repertoire diversity against an immunodominant $\mathrm{M} 1$ peptide antigen comparing young ( $>18$ yoa) and elderly ( $>61$ yoa) adults, the young adults had more TCRs with public TCRs (those shared among different individuals) and fewer private TCRs (those unique to an individual). Elderly adults had low percentages of public TCRs and higher proportions of expanded private clonal populations (Sant et al. 2018b). Other features of TCRs from older individuals included relatively long complementarity determining 3 regions (CDR3), with increased G/A runs (Gil et al. 2015). The investigators suggest these features convey molecular flexibility in recognizing different peptides, theoretically making the T-cell recognition of antigens more degenerate (Gil et al. 2015). Greater TCR diversity was observed in elderly subjects with severe H7N9 infection, suggesting the capacity to recruit and expand a more diverse repertoire from low frequency T-cell clones (Sant et al. 2018b). Various publications suggest increasing defects in $\mathrm{CD}^{+}$T-cell effector functions with age (McElhaney et al. 2016; Goronzy and Weyand 2017). However, an exhaustive study of $\mathrm{CD} 8^{+} \mathrm{T}$ cell responses to respiratory syncytial virus (RSV) comparing younger and older adults in their ability to produce multiple effector cytokines, there were no numerical or effector func- tion differences detected (Roumanes et al 2018). Despite reductions in receptor diversity, $\mathrm{CD}^{+} \mathrm{T}$ cells from older subjects nevertheless appear to retain their ability to respond to their cognate antigens. The reduced diversity may affect responses to newly emerged viruses, but the degree of conservation among the internal proteins should preserve heterologous immunity.

\section{ACKNOWLEDGMENT}

This article has been made freely available online courtesy of TAUNS Laboratories.

\section{REFERENCES}

Abelleira R, Ruano-Ravina A, Lama A, Barbeito G, Toubes ME, Domínguez-Antelo C, González-Barcala FJ, Rodríguez-Núñez N, Marcos PJ, Pérez Del Molino ML, et al. 2019. Influenza A H1N1 community-acquired pneumonia: characteristics and risk factors-a case-control study. Can Respir J 2019: 4301039. doi:10.1155/2019/4301039

Ahrends T, Spanjaard A, Pilzecker B, Bąbała N, Bovens A, Xiao Y, Jacobs H, Borst J. 2017. CD4 ${ }^{+}$T cell help confers a cytotoxic $\mathrm{T}$ cell effector program including coinhibitory receptor downregulation and increased tissue invasiveness. Immunity 47: 848-861.e5. doi:10.1016/j.immuni 2017.10.009

Aiba Y, Kometani K, Hamadate M, Moriyama S, SakaueSawano A, Tomura M, Luche H, Fehling HJ, Casellas R, Kanagawa O, et al. 2010. Preferential localization of IgG memory B cells adjacent to contracted germinal centers. Proc Natl Acad Sci 107: 12192-12197. doi:10.1073/pnas .1005443107

Alam S, Sant AJ. 2011. Infection with seasonal influenza virus elicits $\mathrm{CD} 4 \mathrm{~T}$ cells specific for genetically conserved epitopes that can be rapidly mobilized for protective immunity to pandemic H1N1 influenza virus. J Virol 85: 13310-13321. doi:10.1128/JVI.05728-11

Alam S, Knowlden ZA, Sangster MY, Sant AJ. 2014. CD4 T cell help is limiting and selective during the primary B cell response to influenza virus infection. J Virol 88: 314-324. doi:10.1128/JVI.02077-13

Alam S, Chan C, Qiu X, Shannon I, White CL, Sant AJ, Nayak JL. 2017. Selective pre-priming of HA-specific $\mathrm{CD} 4 \mathrm{~T}$ cells restores immunological reactivity to HA on heterosubtypic influenza infection. PLOS ONE 12: e0176407. doi:10.1371/journal.pone.0176407

Allen JD, Ross TM. 2018. H3N2 influenza viruses in humans: viral mechanisms, evolution, and evaluation. Hum Vaccin Immunother 14: 1840-1847. doi:10.1080/ 21645515.2018.1462639

Allie SR, Randall TD. 2017. Pulmonary immunity to viruses Clin Sci (Lond) 131: 1737-1762. doi:10.1042/CS201 60259

Alymova IV, Green AM, van de Velde N, McAuley JL, Boyd KL, Ghoneim HE, McCullers JA. 2011. Immunopatho- 
D.J. Topham et al.

genic and antibacterial effects of $\mathrm{H} 3 \mathrm{~N} 2$ influenza $\mathrm{A}$ virus PB1-F2 map to amino acid residues $62,75,79$, and 82 . J Virol 85: 12324-12333. doi:10.1128/JVI.05872-11

Alymova IV, Samarasinghe A, Vogel P, Green AM, Weinlich R, McCullers JA. 2014. A novel cytotoxic sequence contributes to influenza A viral protein PB1-F2 pathogenicity and predisposition to secondary bacterial infection J Virol 88: 503-515. doi:10.1128/JVI.01373-13

Alymova IV, McCullers JA, Kamal RP, Vogel P, Green AM, Gansebom S, York IA. 2018. Virulent PB1-F2 residues: effects on fitness of H1N1 influenza A virus in mice and changes during evolution of human influenza A viruses. Sci Rep 8: 7474. doi:10.1038/s41598-018-25707-y

Anastasina M, Le May N, Bugai A, Fu Y, Söderholm S, Gaelings L, Ohman T, Tynell J, Kyttänen S, Barboric M et al. 2016. Influenza virus NS1 protein binds cellular DNA to block transcription of antiviral genes. Biochim Biophys Acta 1859: 1440-1448. doi:10.1016/j.bbagrm .2016 .09 .005

Andrews SF, Chambers MJ, Schramm CA, Plyler J, Raab JE, Kanekiyo M, Gillespie RA, Ransier A, Darko S, Hu J, et al. 2019. Activation dynamics and immunoglobulin evolution of pre-existing and newly generated human memory $\mathrm{B}$ cell responses to influenza hemagglutinin. Immunity 51: 398-410.e5. doi:10.1016/j.immuni.2019.06.024

Arpaia N, Green JA, Moltedo B, Arvey A, Hemmers S, Yuan S, Treuting PM, Rudensky AY. 2015. A distinct function of regulatory T cells in tissue protection. Cell 162: 10781089. doi:10.1016/j.cell.2015.08.021

Assarsson E, Bui HH, Sidney J, Zhang Q, Glenn J, Oseroff C, Mbawuike IN, Alexander J, Newman MJ, Grey H, et al 2008. Immunomic analysis of the repertoire of T-cell specificities for influenza A virus in humans. J Virol 82: 12241-12251. doi:10.1128/JVI.01563-08

Babon JA, Cruz J, Orphin L, Pazoles P, Co MD, Ennis FA, Terajima M. 2009. Genome-wide screening of human Tcell epitopes in influenza A virus reveals a broad spectrum of $\mathrm{CD} 4^{+} \mathrm{T}$-cell responses to internal proteins, hemagglutinins, and neuraminidases. Hum Immunol 70: 711-721. doi:10.1016/j.humimm.2009.06.004

Bautista BL, Devarajan P, McKinstry KK, Strutt TM, Vong AM, Jones MC, Kuang Y, Mott D, Swain SL. 2016. Shortlived antigen recognition but not viral infection at a defined checkpoint programs effector CD4 T cells to become protective memory. J Immunol 197: 3936-3949. doi:10.4049/jimmunol.1600838

Bavagnoli L, Cucuzza S, Campanini G, Rovida F, Paolucci S, Baldanti F, Maga G. 2015. The novel influenza A virus protein PA-X and its naturally deleted variant show different enzymatic properties in comparison to the viral endonuclease PA. Nucleic Acids Res 43: 9405-9417. doi:10.1093/nar/gkv926

Beauchamp NM, Yammani RD, Alexander-Miller MA. 2012. CD8 marks a subpopulation of lung-derived dendritic cells with differential responsiveness to viral infection and Toll-like receptor stimulation. J Virol 86: 10640-10650. doi:10.1128/JVI.01413-12

Bedoui S, Heath WR, Mueller SN. 2016. CD4 ${ }^{+}$T-cell help amplifies innate signals for primary $\mathrm{CD}^{+} \mathrm{T}$-cell immunity. Immunol Rev 272: 52-64. doi:10.1111/imr.12426

Belz GT, Smith CM, Kleinert L, Reading P, Brooks A, Shortman K, Carbone FR, Heath WR. 2004. Distinct migrating and nonmigrating dendritic cell populations are involved in MHC class I-restricted antigen presentation after lung infection with virus. Proc Natl Acad Sci 101: 8670-8675. doi:10.1073/pnas.0402644101

Bennink J, Effros RB, Doherty PC. 1978. Influenzal pneumonia: early appearance of cross-reactive $\mathrm{T}$ cells in lungs of mice primed with heterologous type A viruses. Immunology 35: 503-509.

Bentebibel SE, Lopez S, Obermoser G, Schmitt N, Mueller C, Harrod C, Flano E, Mejias A, Albrecht RA, Blankenship $\mathrm{D}$, et al. 2013. Induction of $\mathrm{ICOS}^{+} \mathrm{CXCR}^{+}{ }^{+} \mathrm{CXCR}^{+} \mathrm{T}_{\mathrm{H}}$ cells correlates with antibody responses to influenza vaccination. Sci Transl Med 5: 176ra32. doi:10.1126/sci translmed.3005191

Bentebibel SE, Khurana S, Schmitt N, Kurup P, Mueller C, Obermoser G, Palucka AK, Albrecht RA, García-Sastre A, Golding $\mathrm{H}$, et al. 2016. ICOS ${ }^{+} \mathrm{PD}-1^{+} \mathrm{CXCR} 3^{+} \mathrm{T}$ follicular helper cells contribute to the generation of high-avidity antibodies following influenza vaccination. Sci Rep 6: 26494. doi:10.1038/srep26494

Bergmann M, García-Sastre A, Carnero E, Pehamberger H, Wolff K, Palese P, Muster T. 2000. Influenza virus NS1 protein counteracts PKR-mediated inhibition of replication. J Virol 74: 6203-6206. doi:10.1128/JVI.74.13.62036206.2000

Bermejo-Martin JF, Ortiz de Lejarazu R, Pumarola T, Rello J, Almansa R, Ramírez P, Martin-Loeches I, Varillas D, Gallegos MC, Serón C, et al. 2009. Th1 and Th17 hypercytokinemia as early host response signature in severe pandemic influenza. Crit Care 13: R201. doi:10.1186/ cc8208

Betakova T, Kostrabova A, Lachova V, Turianova L. 2017. Cytokines induced during influenza virus infection. Curr Pharm Des 23: 2616-2622. doi:10.2174/1381612823 666170316123736

Bethell D, Saunders D, Jongkaewwattana A, Kramyu J, Thitithayanont A, Wiboon-ut S, Yongvanitchit K, Limsalakpetch A, Kum-Arb U, Uthaimongkol N, et al. 2013. Evaluation of in vitro cross-reactivity to avian $\mathrm{H} 5 \mathrm{~N} 1$ and pandemic H1N1 2009 influenza following prime boost regimens of seasonal influenza vaccination in healthy human subjects: a randomised trial. PLoS ONE 8: e59674. doi:10.1371/journal.pone.0059674

Betts MR, Nason MC, West SM, De Rosa SC, Migueles SA, Abraham J, Lederman MM, Benito JM, Goepfert PA, Connors M, et al. 2006. HIV nonprogressors preferentially maintain highly functional $\mathrm{HIV}$-specific $\mathrm{CD} 8^{+} \mathrm{T}$ cells. Blood 107: 4781-4789. doi:10.1182/blood-2005-12-4818

Bevan MJ. 2004. Helping the CD8 ${ }^{+}$T-cell response. Nat Rev Immunol 4: 595-602. doi:10.1038/nri1413

Both GW, Sleigh MJ, Cox NJ, Kendal AP. 1983. Antigenic drift in influenza virus H3 hemagglutinin from 1968 to 1980: multiple evolutionary pathways and sequential amino acid changes at key antigenic sites. J Virol 48: $52-60$.

Boudreau CM, Alter G. 2019. Extra-neutralizing FcR-mediated antibody functions for a universal influenza vaccine. Front Immunol 10: 440. doi:10.3389/fimmu.2019.00440

Breitfeld D, Ohl L, Kremmer E, Ellwart J, Sallusto F, Lipp M, Förster R. 2000. Follicular B helper T cells express CXC chemokine receptor 5 , localize to $\mathrm{B}$ cell follicles, and sup- 
port immunoglobulin production. J Exp Med 192: 15451552. doi:10.1084/jem.192.11.1545

Brincks EL, Katewa A, Kucaba TA, Griffith TS, Legge KL. 2008. CD8 T cells utilize TRAIL to control influenza virus infection. J Immunol 181: 4918-4925. doi:10.4049/jimmu nol.181.7.4918

Brincks EL, Roberts AD, Cookenham T, Sell S, Kohlmeier JE, Blackman MA, Woodland DL. 2013. Antigen-specific memory regulatory $\mathrm{CD} 4^{+} \mathrm{Foxp}^{+} \mathrm{T}$ cells control memory responses to influenza virus infection. J Immunol 190: 3438-3446. doi:10.4049/jimmunol.1203140

Brown DM, Lee S, García-Hernandez Mde L, Swain SL. 2012. Multifunctional CD4 cells expressing gamma interferon and perforin mediate protection against lethal influenza virus infection. J Virol 86: 6792-6803. doi:10 .1128/JVI.07172-11

Brown DM, Lampe AT, Workman AM. 2016. The differentiation and protective function of cytolytic CD4 T cells in influenza infection. Front Immunol 7: 93. doi:10.3389/ fimmu.2016.00093

Calzas C, Chevalier C. 2019. Innovative mucosal vaccine formulations against influenza A virus infections. Front Immunol 10: 1605. doi:10.3389/fimmu.2019.01605

Carrat F, Flahault A. 2007. Influenza vaccine: the challenge of antigenic drift. Vaccine 25: 6852-6862. doi:10.1016/j .vaccine.2007.07.027

Cauley LS. 2016. Environmental cues orchestrate regional immune surveillance and protection by pulmonary CTLs. J Leukoc Biol 100: 905-912. doi:10.1189/jlb.1MR 0216-074R

CDC. 2018. Estimated influenza illnesses, medical visits, hospitalizations, and deaths in the United States2017-2018 influenza season. CDC, Atlanta.

Chauché C, Nogales A, Zhu H, Goldfarb D, Ahmad Shanizza AI, Gu Q, Parrish CR, Martínez-Sobrido L, Marshall JF, Murcia PR. 2018. Mammalian adaptation of an avian influenza A virus involves stepwise changes in NS1. J Virol 92: $\mathrm{e} 01875-17$

Chen Z, Li Y, Krug RM. 1999. Influenza A virus NS1 protein targets poly(A)-binding protein II of the cellular $3^{\prime}$-end processing machinery. EMBO J 18: 2273-2283. doi:10 $.1093 / \mathrm{emboj} / 18.8 .2273$

Chen W, Calvo PA, Malide D, Gibbs J, Schubert U, Bacik I, Basta S, O’Neill R, Schickli J, Palese P, et al. 2001. A novel influenza A virus mitochondrial protein that induces cell death. Nat Med 7: 1306-1312. doi:10.1038/nm1201-1306

Chen L, Zanker D, Xiao K, Wu C, Zou Q, Chen W. 2014 Immunodominant $\mathrm{CD}^{+}{ }^{+} \mathrm{T}$-cell responses to influenza $\mathrm{A}$ virus in healthy individuals focus on matrix 1 and nucleoprotein. J Virol 88: 11760-11773. doi:10.1128/JVI .01631-14

Chen X, Liu S, Goraya MU, Maarouf M, Huang S, Chen JL. 2018. Host immune response to influenza A virus infection. Front Immunol 9: 320. doi:10.3389/fimmu.2018 .00320

Cheong WC, Kang HR, Yoon H, Kang SJ, Ting JP, Song MJ. 2015. Influenza A virus NS1 protein inhibits the NLRP3 inflammasome. PLoS ONE 10: e0126456. doi:10.1371/ journal.pone.0126456

Chevalier N, Jarrossay D, Ho E, Avery DT, Ma CS, Yu D, Sallusto F, Tangye SG, Mackay CR. 2011. CXCR5 express- ing human central memory CD4 T cells and their relevance for humoral immune responses. J Immunol 186: 5556-5568. doi:10.4049/jimmunol.1002828

Chu KL, Batista NV, Wang KC, Zhou AC, Watts TH. 2019. GITRL on inflammatory antigen presenting cells in the lung parenchyma provides signal 4 for T-cell accumulation and tissue-resident memory T-cell formation. Mucosal Immunol 12: 363-377. doi:10.1038/s41385018-0105-5

Clark AM, DeDiego ML, Anderson CS, Wang J, Yang H, Nogales A, Martinez-Sobrido L, Zand MS, Sangster MY, Topham DJ. 2017a. Antigenicity of the 2015-2016 seasonal H1N1 human influenza virus HA and NA proteins. PLOS ONE 12: e0188267. doi:10.1371/journal.pone .0188267

Clark AM, Nogales A, Martinez-Sobrido L, Topham DJ, DeDiego ML. 2017b. Functional evolution of influenza virus NS1 protein in currently circulating human 2009 pandemic H1N1 viruses. J Virol 91: e00721e00-17.

Clemens MJ, Williams BR. 1978. Inhibition of cell-free protein synthesis by pppA2' $5^{\prime} \mathrm{A} 2^{\prime} \mathrm{p}^{\prime} \mathrm{A}$ : a novel oligonucleotide synthesized by interferon-treated $\mathrm{L}$ cell extracts. Cell 13: 565-572. doi:10.1016/0092-8674(78)90329-X

Cobey S, Hensley SE. 2017. Immune history and influenza virus susceptibility. Curr Opin Virol 22: 105-111. doi:10 .1016/j.coviro.2016.12.004

Conenello GM, Zamarin D, Perrone LA, Tumpey T, Palese P. 2007. A single mutation in the PB1-F2 of H5N1 (HK/97) and 1918 influenza A viruses contributes to increased virulence. PLoS Pathog 3: e141. doi:10.1371/journal.ppat .0030141

Crooke SN, Ovsyannikova IG, Poland GA, Kennedy RB. 2019. Immunosenescence and human vaccine immune responses. Immun Ageing 16: 25. doi:10.1186/s12979019-0164-9

Crotty S. 2015. A brief history of T cell help to B cells. Nat Rev Immunol 15: 185-189. doi:10.1038/nri3803

Cyster JG, Allen CDC. 2019. B cell responses: cell interaction dynamics and decisions. Cell 177: 524-540. doi:10.1016/j .cell.2019.03.016

Darton TC, Blohmke CJ, Moorthy VS, Altmann DM, Hayden FG, Clutterbuck EA, Levine MM, Hill AV, Pollard AJ. 2015. Design, recruitment, and microbiological considerations in human challenge studies. Lancet Infect Dis 15: 840-851. doi:10.1016/S1473-3099(15)00068-7

DeDiego ML, Anderson CS, Yang H, Holden-Wiltse J, Fitzgerald T, Treanor JJ, Topham DJ. 2016a. Directed selection of influenza virus produces antigenic variants that match circulating human virus isolates and escape from vaccine-mediated immune protection. Immunology 148: 160-173. doi:10.1111/imm.12594

DeDiego ML, Nogales A, Lambert-Emo K, Martinez-Sobrido L, Topham DJ. 2016b. NS1 protein mutation I64T affects interferon responses and virulence of circulating H3N2 human influenza A viruses. J Virol 90: 9693-9711. doi:10.1128/JVI.01039-16

de Jong JC, Palache AM, Beyer WE, Rimmelzwaan GF, Boon AC, Osterhaus AD. 2003. Haemagglutination-inhibiting antibody to influenza virus. Dev Biol (Basel) 115: 63-73.

de Jong MD, Simmons CP, Thanh TT, Hien VM, Smith GJD, Chau TNB, Hoang DM, Chau NVV, Khanh TH, Dong VC, et al. 2006. Fatal outcome of human influenza A 
D.J. Topham et al.

(H5N1) is associated with high viral load and hypercytokinemia. Nat Med 12: 1203-1207. doi:10.1038/nm1477

de Wit E, Siegers JY, Cronin JM, Weatherman S, van den Brand JM, Leijten LM, van Run P, Begeman L, van den Ham HJ, Andeweg AC, et al. 2018. 1918 H1N1 influenza virus replicates and induces proinflammatory cytokine responses in extrarespiratory tissues of ferrets. J Infect Dis 217: 1237-1246. doi:10.1093/infdis/jiy003

den Haan JM, Bevan MJ. 2001. Antigen presentation to $\mathrm{CD}^{+} \mathrm{T}$ cells: cross-priming in infectious diseases. Curr Opin Immunol 13: 437-441. doi:10.1016/S0952-7915(00) 00238-7

DiLillo DJ, Palese P, Wilson PC, Ravetch JV. 2016. Broadly neutralizing anti-influenza antibodies require $\mathrm{Fc}$ receptor engagement for in vivo protection. J Clin Invest 126: 605610. doi:10.1172/JCI84428

DiPiazza A, Nogales A, Poulton N, Wilson PC, MartínezSobrido L, Sant AJ. 2017. Pandemic 2009 H1N1 Influenza Venus reporter virus reveals broad diversity of MHC class II-positive antigen-bearing cells following infection in vivo. Sci Rep 7: 10857. doi:10.1038/s41598-017-11313-x

DiPiazza AT, Fan S, Rattan A, DeDiego ML, Chaves F, Neumann G, Kawaoka Y, Sant AJ. 2019. A novel vaccine strategy to overcome poor immunogenicity of avian influenza vaccines through mobilization of memory $\mathrm{CD} 4 \mathrm{~T}$ cells established by seasonal influenza. J Immunol 203: 1502-1508. doi:10.4049/jimmunol.1900819

Di Pucchio T, Chatterjee B, Smed-Sörensen A, Clayton S, Palazzo A, Montes M, Xue Y, Mellman I, Banchereau J, Connolly JE. 2008. Direct proteasome-independent cross-presentation of viral antigen by plasmacytoid dendritic cells on major histocompatibility complex class I. Nat Immunol 9: 551-557. doi:10.1038/ni.1602

Dobrzanski MJ, Reome JB, Hollenbaugh JA, Dutton RW. 2004. Tc1 and Tc2 effector cell therapy elicit long-term tumor immunity by contrasting mechanisms that result in complementary endogenous type 1 antitumor responses. J Immunol 172: 1380-1390. doi:10.4049/jimmunol .172 .3 .1380

Duvvuri VR, Moghadas SM, Guo H, Duvvuri B, Heffernan JM, Fisman DN, Wu GE, Wu J. 2010. Highly conserved cross-reactive $\mathrm{CD}^{+}{ }^{+} \mathrm{T}$-cell HA-epitopes of seasonal and the 2009 pandemic influenza viruses. Influenza Other Respir Viruses 4: 249-258. doi:10.1111/j.1750-2659.2010 .00161.x

Duvvuri VR, Duvvuri B, Jamnik V, Gubbay JB, Wu J, Wu GE. 2013. T cell memory to evolutionarily conserved and shared hemagglutinin epitopes of H1N1 viruses: a pilot scale study. BMC Infect Dis 13: 204. doi:10.1186/14712334-13-204

Egarnes B, Gosselin J. 2018. Contribution of regulatory T cells in nucleotide-binding oligomerization domain 2 response to influenza virus infection. Front Immunol 9: 132. doi:10.3389/fimmu.2018.00132

Ehrhardt C, Wolff T, Pleschka S, Planz O, Beermann W, Bode JG, Schmolke M, Ludwig S. 2007. Influenza A virus NS1 protein activates the PI3K/Akt pathway to mediate antiapoptotic signaling responses. J Virol 81: 3058-3067. doi:10.1128/JVI.02082-06

Eliasson DG, Omokanye A, Schön K, Wenzel UA, Bernasconi V, Bemark M, Kolpe A, El Bakkouri K, Ysenbaert T, Deng L, et al. 2018. M2e-tetramer-specific memory CD4
$\mathrm{T}$ cells are broadly protective against influenza infection Mucosal Immunol 11: 273-289. doi:10.1038/mi.2017.14

Ellebedy AH, Jackson KJL, Kissick HT, Nakaya HI, Davis CW, Roskin KM, McElroy AK, Oshansky CM, Elbein R, Thomas S, et al. 2016. Defining antigen-specific plasmablast and memory B cell subsets in human blood after viral infection or vaccination. Nat Immunol 17: 12261234. doi:10.1038/ni.3533

Fazilleau N, McHeyzer-Williams LJ, Rosen H, McHeyzerWilliams MG. 2009. The function of follicular helper T cells is regulated by the strength of $\mathrm{T}$ cell antigen receptor binding. Nat Immunol 10: 375-384. doi:10.1038/ni.1704

Fernandez-Sesma A, Marukian S, Ebersole BJ, Kaminski D, Park MS, Yuen T, Sealfon SC, García-Sastre A, Moran TM. 2006. Influenza virus evades innate and adaptive immunity via the NS1 protein. J Virol 80: 6295-6304. doi:10.1128/JVI.02381-05

Fonteneau JF, Gilliet M, Larsson M, Dasilva I, Münz C, Liu YJ, Bhardwaj N. 2003. Activation of influenza virus-specific $\mathrm{CD}^{+}$and $\mathrm{CD} 8^{+} \mathrm{T}$ cells: a new role for plasmacytoid dendritic cells in adaptive immunity. Blood 101: 35203526. doi:10.1182/blood-2002-10-3063

Fonville JM, Wilks SH, James SL, Fox A, Ventresca M, Aban M, Xue L, Jones TC, Le NMH, Pham QT, et al. 2014. Antibody landscapes after influenza virus infection or vaccination. Science 346: 996-1000. doi:10.1126/science .1256427

Francis T. 1960. On the doctrine of original antigenic sin. Proc Am Philos Soc 104: 572-578.

Francis ME, King ML, Kelvin AA. 2019. Back to the future for influenza preimmunity-looking back at influenza virus history to infer the outcome of future infections. Viruses 11: E122. doi:10.3390/v11020122

Gack MU, Albrecht RA, Urano T, Inn KS, Huang IC, Carnero E, Farzan M, Inoue S, Jung JU, García-Sastre A. 2009 Influenza A virus NS1 targets the ubiquitin ligase TRIM25 to evade recognition by the host viral RNA sensor RIG-I. Cell Host Microbe 5: 439-449. doi:10.1016/j .chom.2009.04.006

Gao S, Song L, Li J, Zhang Z, Peng H, Jiang W, Wang Q, Kang T, Chen S, Huang W. 2012. Influenza A virus-encoded NS1 virulence factor protein inhibits innate immune response by targeting IKK. Cell Microbiol 14: 1849-1866. doi:10.1111/cmi.12005

Gao R, Bhatnagar J, Blau DM, Greer P, Rollin DC, Denison AM, Deleon-Carnes M, Shieh WJ, Sambhara S, Tumpey TM, et al. 2013. Cytokine and chemokine profiles in lung tissues from fatal cases of 2009 pandemic influenza A (H1N1): role of the host immune response in pathogenesis. Am J Pathol 183: 1258-1268. doi:10.1016/j.ajpath .2013.06.023

Gao H, Sun H, Hu J, Qi L, Wang J, Xiong X, Wang Y, He Q, Lin Y, Kong W, et al. 2015a. Twenty amino acids at the Cterminus of PA-X are associated with increased influenza A virus replication and pathogenicity. J Gen Virol 96: 2036-2049. doi:10.1099/vir.0.000143

Gao H, Sun Y, Hu J, Qi L, Wang J, Xiong X, Wang Y, He Q, Lin Y, Kong W, et al. 2015b. The contribution of PA-X to the virulence of pandemic 2009 H1N1 and highly pathogenic H5N1 avian influenza viruses. Sci Rep 5: 8262. doi:10.1038/srep08262 
Gao HJ, Xu GL, Sun YP, Qi L, Wang JL, Kong WL, Sun HL, $\mathrm{Pu}$ J, Chang KC, Liu JH. 2015c. PA-X is a virulence factor in avian H9N2 influenza virus. J Gen Virol 96: 2587-2594. doi:10.1099/jgv.0.000232

García-Sastre A, Egorov A, Matassov D, Brandt S, Levy DE, Durbin JE, Palese P, Muster T. 1998. Influenza A virus lacking the NS1 gene replicates in interferon-deficient systems. Virology 252: 324-330. doi:10.1006/viro.1998 .9508

Geginat J, Sallusto F, Lanzavecchia A. 2001. Cytokine-driven proliferation and differentiation of human naive, central memory, and effector memory $\mathrm{CD}^{+}{ }^{+} \mathrm{T}$ cells. J Exp Med 194: 1711-1720. doi:10.1084/jem.194.12.1711

Gil A, Yassai MB, Naumov YN, Selin LK. 2015. Narrowing of human influenza A virus-specific T cell receptor $\alpha$ and $\beta$ repertoires with increasing age. J Virol 89: 4102-4116. doi:10.1128/JVI.03020-14

Good-Jacobson KL. 2018. Strength in diversity: phenotypic, functional, and molecular heterogeneity within the memory B cell repertoire. Immunol Rev 284: 67-78. doi:10 $.1111 / \mathrm{imr} .12663$

Goronzy JJ, Weyand CM. 2017. Successful and maladaptive $\mathrm{T}$ cell aging. Immunity 46: 364-378. doi:10.1016/j .immuni.2017.03.010

Graef KM, Vreede FT, Lau YF, McCall AW, Carr SM, Subbarao K, Fodor E. 2010. The PB2 subunit of the influenza virus RNA polymerase affects virulence by interacting with the mitochondrial antiviral signaling protein and inhibiting expression of $\beta$ interferon. J Virol 84: 84338445. doi:10.1128/JVI.00879-10

Grant EJ, Quiñones-Parra SM, Clemens EB, Kedzierska K. 2016. Human influenza viruses and $\mathrm{CD} 8^{+} \mathrm{T}$ cell respons es. Curr Opin Virol 16: 132-142. doi:10.1016/j.coviro .2016 .01 .016

Grant EJ, Josephs TM, Loh L, Clemens EB, Sant S, Bharadwaj M, Chen W, Rossjohn J, Gras S, Kedzierska K. 2018. Broad CD8 ${ }^{+} \mathrm{T}$ cell cross-recognition of distinct influenza A strains in humans. Nat Commun 9: 5427. doi:10.1038/ s41467-018-07815-5

Gustafson CE, Weyand CM, Goronzy JJ. 2018. T follicular helper cell development and functionality in immune ageing. Clin Sci (Lond) 132: 1925-1935. doi:10.1042/ CS20171157

Guthmiller JJ, Wilson PC. 2018. Harnessing immune history to combat influenza viruses. Curr Opin Immunol 53: 187195. doi:10.1016/j.coi.2018.05.010

Hale JS, Ahmed R. 2015. Memory T follicular helper CD4T cells. Front Immunol 6: 16. doi:10.1126/sciimmunol. aag0851

Hale BG, Jackson D, Chen YH, Lamb RA, Randall RE. 2006. Influenza $A$ virus NS1 protein binds $\mathrm{p} 85 \beta$ and activates phosphatidylinositol-3-kinase signaling. Proc Natl Acad Sci 103: 14194-14199. doi:10.1073/pnas.0606109103

Hale BG, Steel J, Medina RA, Manicassamy B, Ye J, Hickman D, Hai R, Schmolke M, Lowen AC, Perez DR, et al. 2010 Inefficient control of host gene expression by the 2009 pandemic H1N1 influenza A virus NS1 protein. J Virol 84: 6909-6922. doi:10.1128/JVI.00081-10

Halliley Jessica L, Tipton Christopher M, Liesveld J, Rosenberg Alexander F, Darce J, Gregoretti Ivan V, Popova L, Kaminiski D, Fucile Christopher F, Albizua I, et al. 2015. Long-lived plasma cells are contained within the
$\mathrm{CD} 19^{-} \mathrm{CD} 38^{\text {hi }} \mathrm{CD} 138^{+}$subset in human bone marrow. Immunity 43: 132-145. doi:10.1016/j.immuni.2015.06 .016

Hara K, Schmidt FI, Crow M, Brownlee GG. 2006. Amino acid residues in the $\mathrm{N}$-terminal region of the $\mathrm{PA}$ subunit of influenza A virus RNA polymerase play a critical role in protein stability, endonuclease activity, cap binding, and virion RNA promoter binding. J Virol 80: 7789-7798. doi:10.1128/JVI.00600-06

Harandi AM. 2018. Systems analysis of human vaccine adjuvants. Semin Immunol 39: 30-34. doi:10.1016/j.smim 2018.08.001

Hayashi T, MacDonald LA, Takimoto T. 2015. Influenza A virus protein $\mathrm{PA}-\mathrm{X}$ contributes to viral growth and suppression of the host antiviral and immune responses. I Virol 89: 6442-6452. doi:10.1128/JVI.00319-15

Hayashi T, Chaimayo C, McGuinness J, Takimoto T. 2016. Critical role of the PA-X C-terminal domain of influenza A virus in its subcellular localization and shutoff activity. J Virol 90: 7131-7141. doi:10.1128/JVI.00954-16

Hayward AC, Wang L, Goonetilleke N, Fragaszy EB, Bermingham A, Copas A, Dukes O, Millett ER, Nazareth I, Nguyen-Van-Tam JS, et al. 2015. Natural T cell-mediated protection against seasonal and pandemic influenza. results of the Flu Watch Cohort Study. Am J Respir Crit Care Med 191: 1422-1431. doi:10.1164/rccm.201411-1988OC

He J, Tsai LM, Leong YA, Hu X, Ma CS, Chevalier N, Sun X, Vandenberg K, Rockman S, Ding Y, et al. 2013. Circulating precursor $\mathrm{CCR} 7{ }^{\mathrm{lo}} \mathrm{PD}-1^{\text {hi }} \mathrm{CXCR} 5^{+} \mathrm{CD} 4^{+} \mathrm{T}$ cells indicate Tfh cell activity and promote antibody responses upon antigen reexposure. Immunity 39: 770-781. doi:10 .1016/j.immuni.2013.09.007

He W, Chen CJ, Mullarkey CE, Hamilton JR, Wong CK, Leon PE, Uccellini MB, Chromikova V, Henry C, Hoffman KW, et al. 2017. Alveolar macrophages are critical for broadly-reactive antibody-mediated protection against influenza A virus in mice. Nat Commun 8: 846. doi:10 .1038/s41467-017-00928-3

Heit A, Schmitz F, Gerdts S, Flach B, Moore MS, Perkins JA, Robins HS, Aderem A, Spearman P, Tomaras GD, et al. 2017. Vaccination establishes clonal relatives of germinal center T cells in the blood of humans. J Exp Med 214: 2139-2152. doi:10.1084/jem.20161794

Henry C, Palm AKE, Krammer F, Wilson PC. 2018. From original antigenic sin to the universal influenza virus vaccine. Trends Immunol 39: 70-79. doi:10.1016/j.it.2017.08 .003

Henry C, Zheng NY, Huang M, Cabanov A, Rojas KT, Kaur K, Andrews SF, Palm AE, Chen YQ, Li Y, et al. 2019 Influenza virus vaccination elicits poorly adapted B cell responses in elderly individuals. Cell Host Microbe 25: 357-366.e6. doi:10.1016/j.chom.2019.01.002

Herati RS, Reuter MA, Dolfi DV, Mansfield KD, Aung H, Badwan OZ, Kurupati RK, Kannan S, Ertl H, Schmader $\mathrm{KE}$, et al. 2014. Circulating CXCR5 ${ }^{+} \mathrm{PD}-1^{+}$response predicts influenza vaccine antibody responses in young adults but not elderly adults. J Immunol 193: 35283537. doi:10.4049/jimmunol.1302503

Herati RS, Muselman A, Vella L, Bengsch B, Parkhouse K, Del Alcazar D, Kotzin J, Doyle SA, Tebas P, Hensley SE, et al. 2017. Successive annual influenza vaccination induces a recurrent oligoclonotypic memory response in 
D.J. Topham et al.

circulating $\mathrm{T}$ follicular helper cells. Sci Immunol 2: eaag2152. doi:10.1126/sciimmunol.aag2152

Hildemann SK, Eberlein J, Davenport B, Nguyen TT, Victorino F, Homann D. 2013. High efficiency of antiviral $\mathrm{CD}^{+}$killer T cells. PLoS ONE 8: e60420. doi:10.1371/ journal.pone.0060420

Ho AW, Prabhu N, Betts RJ, Ge MQ, Dai X, Hutchinson PE Lew FC, Wong KL, Hanson BJ, Macary PA, et al. 2011. Lung $\mathrm{CD}_{103^{+}}$dendritic cells efficiently transport influenza virus to the lymph node and load viral antigen onto MHC class I for presentation to CD8 T cells. J Immunol 187: 6011-6021. doi:10.4049/jimmunol.1100987

Hrincius ER, Dierkes R, Anhlan D, Wixler V, Ludwig S Ehrhardt C. 2011. Phosphatidylinositol-3-kinase (PI3K) is activated by influenza virus vRNA via the pathogen pattern receptor Rig-I to promote efficient type I interferon production. Cell Microbiol 13: 1907-1919. doi:10 $.1111 / j .1462-5822.2011 .01680 . x$

Hu J, Mo YQ, Wang XQ, Gu M, Hu ZL, Zhong L, Wu QW Hao XL, Hu SL, Liu WB, et al. 2015. PA-X decreases the pathogenicity of highly pathogenic $\mathrm{H} 5 \mathrm{~N} 1$ influenza A virus in avian species by inhibiting virus replication and host response. J Virol 89: 4126-4142. doi:10.1128/JVI $.02132-14$

Hu J, Mo Y, Gao Z, Wang X, Gu M, Liang Y, Cheng X, Hu S, Liu W, Liu H, et al. 2016. PA-X-associated early alleviation of the acute lung injury contributes to the attenuation of a highly pathogenic $\mathrm{H} 5 \mathrm{~N} 1$ avian influenza virus in mice. Med Microbiol Immunol 205: 381-395. doi:10 .1007/s00430-016-0461-2

Hu J, Ma C, Liu X. 2018. PA-X: a key regulator of influenza A virus pathogenicity and host immune responses. Med Microbiol Immunol 207: 255-269. doi: 10.1007/s00430018-0548-Z

Hua L, Yao S, Pham D, Jiang L, Wright J, Sawant D, Dent AL, Braciale TJ, Kaplan MH, Sun J. 2013. Cytokine-dependent induction of $\mathrm{CD}^{+} \mathrm{T}$ cells with cytotoxic potential during influenza virus infection. J Virol 87: 11884-11893. doi:10.1128/JVI.01461-13

Ichikawa A, Kuba K, Morita M, Chida S, Tezuka H, Hara H, Sasaki T, Ohteki T, Ranieri VM, dos Santos CC, et al. 2013. CXCL10-CXCR3 enhances the development of neutrophil-mediated fulminant lung injury of viral and nonviral origin. Am J Respir Crit Care Med 187: 65-77. doi:10.1164/rccm.201203-0508OC

Inoue T, Moran I, Shinnakasu R, Phan TG, Kurosaki T. 2018 Generation of memory B cells and their reactivation. Immunol Rev 283: 138-149. doi:10.1111/imr.12640

Ito T, Allen RM, Carson W, Schaller M, Cavassani KA, Hogaboam CM, Lukacs NW, Matsukawa A, Kunkel SL. 2011. The critical role of Notch ligand Delta-like 1 in the pathogenesis of influenza A virus (H1N1) infection. PLoS Pathog 7: e1002341. doi:10.1371/journal.ppat.1002341

Ivan FX, Tan KS, Phoon MC, Engelward BP, Welsch RE, Rajapakse JC, Chow VT. 2013. Neutrophils infected with highly virulent influenza H3N2 virus exhibit augmented early cell death and rapid induction of type I interferon signaling pathways. Genomics 101: 101-112. doi:10.1016/j.ygeno.2012.11.008

Iwai A, Shiozaki T, Kawai T, Akira S, Kawaoka Y, Takada A Kida H, Miyazaki T. 2010. Influenza A virus polymerase inhibits type I interferon induction by binding to inter- feron $\beta$ promoter stimulator 1. J Biol Chem 285: 3206432074. doi:10.1074/jbc.M110.112458

Iwasaki A, Pillai PS. 2014. Innate immunity to influenza virus infection. Nat Rev Immunol 14: 315-328. doi:10 $.1038 /$ nri3665

Jagger BW, Wise HM, Kash JC, Walters KA, Wills NM, Xiao YL, Dunfee RL, Schwartzman LM, Ozinsky A, Bell GL, et al. 2012. An overlapping protein-coding region in influenza A virus segment 3 modulates the host response. Science 337: 199-204. doi:10.1126/science.1222213

Jansen JM, Gerlach T, Elbahesh H, Rimmelzwaan GF, Saletti G. 2019. Influenza virus-specific $\mathrm{CD} 4^{+}$and $\mathrm{CD} 8^{+} \mathrm{T}$ cellmediated immunity induced by infection and vaccination. J Clin Virol 119: 44-52. doi:10.1016/j.jcv.2019.08 .009

Jegaskanda S, Mason RD, Andrews SF, Wheatley AK, Zhang R, Reynoso GV, Ambrozak DR, Santos CP, Luke CJ, Matsuoka $\mathrm{Y}$, et al. 2018. Intranasal live influenza vaccine priming elicits localized B cell responses in mediastinal lymph nodes. J Virol 92: e01970-17. doi:10.1128/JVI .01970-17

Juno JA, van Bockel D, Kent SJ, Kelleher AD, Zaunders JJ, Munier CM. 2017. Cytotoxic CD4 T cells-friend or foe during viral infection? Front Immunol 8: 19. doi: 10.3389/ fimmu.2017.00019

Kannanganat S, Ibegbu C, Chennareddi L, Robinson HL, Amara RR. 2007. Multiple-cytokine-producing antiviral CD4 T cells are functionally superior to single-cytokineproducing cells. J Virol 81: 8468-8476. doi:10.1128/JVI .00228-07

Kash JC, Tumpey TM, Proll SC, Carter V, Perwitasari O, Thomas MJ, Basler CF, Palese P, Taubenberger JK, García-Sastre A, et al. 2006. Genomic analysis of increased host immune and cell death responses induced by 1918 influenza virus. Nature 443: 578-581. doi:10.1038/na ture05181

Kato A, Hulse KE, Tan BK, Schleimer RP. 2013. B-lymphocyte lineage cells and the respiratory system. J Allergy Clin Immunol 131: 933-957. doi:10.1016/j.jaci.2013.02.023

Kato Y, Zaid A, Davey GM, Mueller SN, Nutt SL, Zotos D, Tarlinton DM, Shortman K, Lahoud MH, Heath WR, et al. 2015. Targeting antigen to Clec9A primes follicular Th cell memory responses capable of robust recall. J Immunol 195: 1006-1014. doi:10.4049/jimmunol.1500767

Keating R, Morris MY, Yue W, Reynolds CE, Harris TL, Brown SA, Doherty PC, Thomas PG, McGargill MA. 2018. Potential killers exposed: tracking endogenous influenza-specific $\mathrm{CD}^{+} \mathrm{T}$ cells. Immunol Cell Biol 96: 1104-1119. doi:10.1111/imcb.12189

Keck S, Schmaler M, Ganter S, Wyss L, Oberle S, Huseby ES, Zehn D, King CG. 2014. Antigen affinity and antigen dose exert distinct influences on CD4 T-cell differentiation. Proc Natl Acad Sci 111: 14852-14857. doi:10.1073/pnas .1403271111

Khaperskyy DA, McCormick C. 2015. Timing is everything: coordinated control of host shutoff by influenza A virus NS1 and PA-X proteins. J Virol 89: 6528-6531. doi:10 .1128/JVI.00386-15

Khaperskyy DA, Schmaling S, Larkins-Ford J, McCormick C, Gaglia MM. 2016. Selective degradation of host RNA polymerase II transcripts by influenza A virus PA-X host 
shutoff protein. PLoS Pathog 12: e1005427. doi:10.1371/ journal.ppat.1005427

Kobasa D, Jones SM, Shinya K, Kash JC, Copps J, Ebihara H, Hatta Y, Kim JH, Halfmann P, Hatta M, et al. 2007. Aberrant innate immune response in lethal infection of macaques with the 1918 influenza virus. Nature 445: 319323. doi:10.1038/nature 05495

Koliopoulos MG, Lethier M, van der Veen AG, Haubrich K, Hennig J, Kowalinski E, Stevens RV, Martin SR, Reis e Sousa C, Cusack S, et al. 2018. Molecular mechanism of influenza A NS1-mediated TRIM25 recognition and inhibition. Nat Commun 9: 1820. doi:10.1038/s41467-01804214-8

Kollmann TR, Crabtree J, Rein-Weston A, Blimkie D, Thommai F, Wang XY, Lavoie PM, Furlong J, Fortuno ES, Hajjar AM, et al. 2009. Neonatal innate TLR-mediated responses are distinct from those of adults. J Immunol 183: 7150-7160. doi:10.4049/jimmunol.0901481

Koutsakos M, Wheatley AK, Loh L, Clemens EB, Sant S, Nüssing S, Fox A, Chung AW, Laurie KL, Hurt AC, et al. 2018. Circulating $\mathrm{T}_{\mathrm{FH}}$ cells, serological memory, and tissue compartmentalization shape human influenza-specific B cell immunity. Sci Transl Med 10: eaan8405. doi:10.1126/scitranslmed.aan8405

Koutsakos M, Illing PT, Nguyen THO, Mifsud NA, Crawford JC, Rizzetto S, Eltahla AA, Clemens EB, Sant S, Chua BY, et al. 2019. Human CD8 ${ }^{+}$T cell cross-reactivity across influenza A, B and C viruses. Nat Immunol 20: 613-625. doi:10.1038/s41590-019-0320-6

Krammer F. 2019. The human antibody response to influenza A virus infection and vaccination. Nat Rev Immunol 19: 383-397. doi:10.1038/s41577-019-0143-6

Krammer F, Palese P. 2013. Influenza virus hemagglutinin stalk-based antibodies and vaccines. Curr Opin Virol 3: 521-530. doi:10.1016/j.coviro.2013.07.007

Krammer F, Palese P. 2015. Advances in the development of influenza virus vaccines. Nat Rev Drug Discov 14: 167182. doi:10.1038/nrd4529

Krangel MS, Taketani S, Biddison WE, Strong DM, Strominger JL. 1982. Comparative structural analysis of HLA-A2 antigens distinguishable by cytotoxic T lymphocytes: variants M7 and DR1. Biochemistry 21: 6313-6321. doi:10.1021/bi00267a042

Krishnamoorthy V, Kannanganat S, Maienschein-Cline M, Cook SL, Chen J, Bahroos N, Sievert E, Corse E, Chong A Sciammas R. 2017. The IRF4 gene regulatory module functions as a read-write integrator to dynamically coordinate Thelper cell fate. Immunity 47: 481-497.e7. doi:10 $.1016 /$ j.immuni.2017.09.001

Krishnaswamy JK, Gowthaman U, Zhang B, Mattsson J, Szeponik L, Liu D, Wu R, White T, Calabro S, Xu L, et al. 2017. Migratory $\mathrm{CD} 11 \mathrm{~b}^{+}$conventional dendritic cells induce $\mathrm{T}$ follicular helper cell-dependent antibody responses. Sci Immunol 2: eaam9169. doi:10.1126/sciim munol.aam9169

Kumar BV, Ma W, Miron M, Granot T, Guyer RS, Carpenter DJ, Senda T, Sun X, Ho SH, Lerner H, et al. 2017. Human tissue-resident memory $\mathrm{T}$ cells are defined by core transcriptional and functional signatures in lymphoid and mucosal sites. Cell Rep 20: 2921-2934. doi:10.1016/j .celrep.2017.08.078
Kytömaa S, Hegde S, Claggett B, Udell JA, Rosamond W Temte J, Nichol K, Wright JD, Solomon SD, Vardeny O. 2019. Association of influenza-like illness activity with hospitalizations for heart failure: the Atherosclerosis Risk in Communities study. JAMA Cardiol 4: 363-369. doi:10.1001/jamacardio.2019.0549

La Gruta NL, Turner SJ. 2014. T cell mediated immunity to influenza: mechanisms of viral control. Trends Immunol 35: 396-402. doi:10.1016/j.it.2014.06.004

Laidlaw BJ, Zhang N, Marshall HD, Staron MM, Guan T, Hu Y, Cauley LS, Craft J, Kaech SM. 2014. CD4 ${ }^{+}$T cell help guides formation of $\mathrm{CD}_{103^{+}}$lung-resident memory $\mathrm{CD}^{+} \mathrm{T}$ cells during influenza viral infection. Immunity 41: 633-645. doi:10.1016/j.immuni.2014.09.007

Lam JH, Baumgarth N. 2019. The multifaceted B cell response to influenza virus. J Immunol 202: 351-359.

Lamb RA, Lai CJ. 1980. Sequence of interrupted and uninterrupted mRNAs and cloned DNA coding for the two overlapping nonstructural proteins of influenza virus. Cell 21: 475-485. doi:10.1016/0092-8674(80)90484-5

Lambert Emo K, Hyun YM, Reilly E, Barilla C, Gerber S, Fowell D, Kim M, Topham DJ. 2016. Live imaging of influenza infection of the trachea reveals dynamic regulation of $\mathrm{CD}^{+} \mathrm{T}$ cell motility by antigen. PLoS Pathog 12 : e1005881. doi:10.1371/journal.ppat.1005881

Lau D, Lan LYL, Andrews SF, Henry C, Rojas KT, Neu KE, Huang M, Huang Y, DeKosky B, Palm AK, et al. 2017. Low CD21 expression defines a population of recent germinal center graduates primed for plasma cell differentiation. Sci Immunol 2: eaai8153. doi:10.1126/sciimmunol .aai8153

Leddon SA, Richards KA, Treanor JJ, Sant AJ. 2015. Abundance and specificity of influenza reactive circulating memory follicular helper and non-follicular helper CD4 $\mathrm{T}$ cells in healthy adults. Immunology 146: 157-162. doi:10.1111/imm.12491

Lee LY, Ha do LA, Simmons C, de Jong MD, Chau NV, Schumacher R, Peng YC, McMichael AJ, Farrar JJ, Smith GL, et al. 2008. Memory T cells established by seasonal human influenza $\mathrm{A}$ infection cross-react with avian influenza A (H5N1) in healthy individuals. J Clin Invest 118: 3478-3490.

Lee J, Yu H, Li Y, Ma J, Lang Y, Duff M, Henningson J, Liu Q, Li Y, Nagy A, et al. 2017. Impacts of different expressions of PA-X protein on 2009 pandemic H1N1 virus replication, pathogenicity and host immune responses. Virology 504: 25-35. doi:10.1016/j.virol.2017.01.015

Lee YT, Ko EJ, Lee Y, Kim KH, Kim MC, Lee YN, Kang SM. 2018. Intranasal vaccination with M2e $5 \mathrm{x}$ virus-like particles induces humoral and cellular immune responses conferring cross-protection against heterosubtypic influenza viruses. PLOS ONE 13: e0190868. doi:10.1371/journal .pone. 0190868

Legge KL, Braciale TJ. 2003. Accelerated migration of respiratory dendritic cells to the regional lymph nodes is limited to the early phase of pulmonary infection. Immunity 18: 265-277. doi:10.1016/S1074-7613(03)00023-2

Le Goffic R, Leymarie O, Chevalier C, Rebours E, Da Costa B, Vidic J, Descamps D, Sallenave JM, Rauch M, Samson M, et al. 2011. Transcriptomic analysis of host immune and cell death responses associated with the influenza A virus 
D.J. Topham et al.

PB1-F2 protein. PLoS Pathog 7: e1002202. doi:10.1371/ journal.ppat.1002202

Lessler J, Riley S, Read JM, Wang S, Zhu H, Smith GJD, Guan Y, Jiang CQ, Cummings DAT. 2012. Evidence for antigenic seniority in influenza A (H3N2) antibody responses in Southern China. PLoS Pathog 8: e1002802. doi:10 .1371/journal.ppat.1002802

Levene RE, Gaglia MM. 2018. Host shutoff in influenza A virus: many means to an end. Viruses 10: 475 . doi:10 .3390/v10090475

Lewnard JA, Cobey S. 2018. Immune history and influenza vaccine effectiveness. Vaccines (Basel) 6: 28.

Li S, Min JY, Krug RM, Sen GC. 2006. Binding of the influenza A virus NS1 protein to PKR mediates the inhibition of its activation by either PACT or double-stranded RNA. Virology 349: 13-21. doi:10.1016/j.virol.2006.01.005

Li ZT, Zarnitsyna VI, Lowen AC, Weissman D, Koelle K, Kohlmeier JE, Antia R. 2019. Why are CD8 T cell epitopes of human influenza A virus conserved? J Virol 93: e01534-18. doi:10.1128/JVI.01534-18

Liechti T, Roederer M. 2019. OMIP-060-30-parameter flow cytometry panel to assess $\mathrm{T}$ cell effector functions and regulatory T cells. Cytometry A 95: 1129-1134. doi:10 $.1002 /$ cyto.a. 23853

Lillie PJ, Berthoud TK, Powell TJ, Lambe T, Mullarkey C, Spencer AJ, Hamill M, Peng Y, Blais ME, Duncan CJ, et al. 2012. Preliminary assessment of the efficacy of a T-cellbased influenza vaccine, MVA-NP+M1, in humans. Clin Infect Dis 55: 19-25. doi:10.1093/cid/cis327

Lim K, Hyun YM, Lambert-Emo K, Capece T, Bae S, Miller R, Topham DJ, Kim M. 2015. Neutrophil trails guide influenza-specific $\mathrm{CD}^{+} \mathrm{T}$ cells in the airways. Science 349: aaa4352. doi:10.1126/science.aaa4352

Linterman MA, Hill DL. 2016. Can follicular helper T cells be targeted to improve vaccine efficacy? F1000Res 5: 88 . doi:10.12688/f1000research.7388.1

Little R, White MR, Hartshorn KL. 1994. Interferon- $\alpha$ enhances neutrophil respiratory burst responses to stimulation with influenza A virus and FMLP. J Infect Dis 170: 802-810. doi:10.1093/infdis/170.4.802

Liu WC, Nachbagauer R, Stadlbauer D, Solórzano A, Berlanda-Scorza F, García-Sastre A, Palese P, Krammer F, Albrecht RA. 2019. Sequential immunization with liveattenuated chimeric hemagglutinin-based vaccines confers heterosubtypic immunity against influenza A viruses in a preclinical ferret model. Front Immunol 10: 756. doi:10.3389/fimmu.2019.00756

Locci M, Havenar-Daughton C, Landais E, Wu J, Kroenke MA, Arlehamn CL, Su LF, Cubas R, Davis MM, Sette A et al. 2013. Human circulating PD $-1^{+} \mathrm{CXCR}^{-}{ }^{-} \mathrm{CXCR}^{+}$ memory Tfh cells are highly functional and correlate with broadly neutralizing HIV antibody responses. Immunity 39: 758-769. doi:10.1016/j.immuni.2013.08.031

Lohrmann F, Dijkman R, Stertz S, Thiel V, Haller O, Staeheli P, Kochs G. 2013. Emergence of a C-terminal seven-amino-acid elongation of NS1 in around 1950 conferred a minor growth advantage to former seasonal influenza A viruses. J Virol 87: 11300-11303. doi:10.1128/JVI .01271-13

Lorenzo EC, Bartley JM, Haynes L. 2018. The impact of aging on $\mathrm{CD}^{+} \mathrm{T}$ cell responses to influenza infection.
Biogerontology 19: 437-446. doi:10.1007/s10522-0189754-8

Lu Y, Wambach M, Katze MG, Krug RM. 1995. Binding of the influenza virus NS1 protein to double-stranded RNA inhibits the activation of the protein kinase that phosphorylates the eIF-2 translation initiation factor. Virology 214: 222-228. doi:10.1006/viro.1995.9937

Lu X, Masic A, Liu Q, Zhou Y. 2011. Regulation of influenza A virus induced CXCL-10 gene expression requires PI3K/ Akt pathway and IRF3 transcription factor. Mol Immunol 48: 1417-1423. doi:10.1016/j.molimm.2011.03.017

Ludwig S, Wang X, Ehrhardt C, Zheng H, Donelan N, Planz O, Pleschka S, García-Sastre A, Heins G, Wolff T. 2002. The influenza A virus NS1 protein inhibits activation of Jun N-terminal kinase and AP-1 transcription factors. J Virol 76: 11166-11171. doi:10.1128/JVI.76.21.1116611171.2002

Lui G, Manches O, Angel J, Molens JP, Chaperot L, Plumas J. 2009. Plasmacytoid dendritic cells capture and cross-present viral antigens from influenza-virus exposed cells PLoS ONE 4: e7111. doi:10.1371/journal.pone.0007111

Marc D. 2014. Influenza virus non-structural protein NS1: interferon antagonism and beyond. J Gen Virol 95: 25942611. doi:10.1099/vir.0.069542-0

Margine I, Hai R, Albrecht RA, Obermoser G, Harrod AC, Banchereau J, Palucka K, García-Sastre A, Palese P, Treanor JJ, et al. 2013. H3N2 Influenza virus infection induces broadly reactive hemagglutinin stalk antibodies in humans and mice. J Virol 87: 4728-4737. doi:10.1128/JVI .03509-12

Marshall NB, Vong AM, Devarajan P, Brauner MD, Kuang Y, Nayar R, Schutten EA, Castonguay CH, Berg LJ, Nutt SL, et al. 2017. NKG2C/E marks the unique cytotoxic CD4 T cell subset, ThCTL, generated by influenza infection. J Immunol 198: 1142-1155. doi:10.4049/jimmunol .1601297

Mastelic Gavillet B, Eberhardt CS, Auderset F, Castellino F, Seubert A, Tregoning JS, Lambert PH, de Gregorio E, Del Giudice G, Siegrist CA. 2015. MF59 mediates its B cell adjuvanticity by promoting $\mathrm{T}$ follicular helper cells and thus germinal center responses in adult and early life. J Immunol 194: 4836-4845. doi:10.4049/jimmunol .1402071

Matsuda K, Huang J, Zhou T, Sheng Z, Kang BH, Ishida E, Griesman T, Stuccio S, Bolkhovitinov L, Wohlbold TJ, et al. 2019. Prolonged evolution of the memory B cell response induced by a replicating adenovirus-influenza H5 vaccine. Sci Immunol 4: eaau2710. doi:10.1126/sciim munol.aau2710

Mauad T, Hajjar LA, Callegari GD, da Silva LF, Schout D, Galas FR, Alves VA, Malheiros DM, Auler JO, Ferreira AF, et al. 2010. Lung pathology in fatal novel human influenza A (H1N1) infection. Am J Respir Crit Care Med 181: 7279. doi:10.1164/rccm.200909-1420OC

Mazur I, Anhlan D, Mitzner D, Wixler L, Schubert U, Ludwig S. 2008. The proapoptotic influenza A virus protein PB1-F2 regulates viral polymerase activity by interaction with the PB1 protein. Cell Microbiol 10: 1140-1152. doi:10.1111/j.1462-5822.2008.01116.x

McAuley JL, Hornung F, Boyd KL, Smith AM, McKeon R, Bennink J, Yewdell JW, McCullers JA. 2007. Expression of the 1918 influenza A virus PB1-F2 enhances the patho- 
genesis of viral and secondary bacterial pneumonia. Cell Host Microbe 2: 240-249. doi:10.1016/j.chom.2007.09 .001

McAuley JL, Tate MD, MacKenzie-Kludas CJ, Pinar A, Zeng W, Stutz A, Latz E, Brown LE, Mansell A. 2013. Activation of the NLRP3 inflammasome by IAV virulence protein PB1-F2 contributes to severe pathophysiology and disease. PLoS Pathog 9: e1003392. doi:10.1371/journal.ppat .1003392

McElhaney JE, Kuchel GA, Zhou X, Swain SL, Haynes L. 2016. T-cell immunity to influenza in older adults: a pathophysiological framework for development of more effective vaccines. Front Immunol 7: 41. doi:10.3389/fimmu .2016 .00041

McGill J, Van Rooijen N, Legge KL. 2008. Protective influenza-specific CD8 $\mathrm{T}$ cell responses require interactions with dendritic cells in the lungs. J Exp Med 205: 16351646. doi:10.1084/jem.20080314

McKinstry KK, Strutt TM, Kuang Y, Brown DM, Sell S, Dutton RW, Swain SL. 2012. Memory $\mathrm{CD}^{+}{ }^{+} \mathrm{T}$ cells protect against influenza through multiple synergizing mechanisms. J Clin Invest 122: 2847-2856. doi:10.1172/ JCI63689

McMichael AJ, Gotch FM, Noble GR, Beare PA. 1983. Cytotoxic T-cell immunity to influenza. N Engl J Med 309: 13-17. doi:10.1056/NEJM198307073090103

Mertz D, Lo CK, Lytvyn L, Ortiz JR, Loeb M, for the FLURISK INVESTIGATORS. 2019. Pregnancy as a risk factor for severe influenza infection: an individual participant data meta-analysis. BMC Infect Dis 19: 683. doi:10.1186/ s12879-019-4318-3

Mesin L, Ersching J, Victora Gabriel D. 2016. Germinal center B cell dynamics. Immunity 45: 471-482. doi:10 .1016/j.immuni.2016.09.001

Mibayashi M, Martinez-Sobrido L, Loo YM, Cardenas WB, Gale M Jr, García-Sastre A. 2007. Inhibition of retinoic acid-inducible gene I-mediated induction of $\beta$ interferon by the NS1 protein of influenza A virus. J Virol 81: 514524. doi:10.1128/JVI.01265-06

Min JY, Krug RM. 2006. The primary function of RNA binding by the influenza A virus NS1 protein in infected cells: inhibiting the $2^{\prime}-5^{\prime}$ oligo (A) synthetase/RNase L pathway. Proc Natl Acad Sci 103: 7100-7105. doi:10 .1073/pnas.0602184103

Min JY, Li S, Sen GC, Krug RM. 2007. A site on the influenza A virus NS1 protein mediates both inhibition of PKR activation and temporal regulation of viral RNA synthesis. Virology 363: 236-243. doi:10.1016/j.virol.2007.01 .038

Moise L, M Biron B, Boyle CM, Kurt Yilmaz N, Jang H, Schiffer C, M Ross T, Martin WD, De Groot AS. 2018. $\mathrm{T}$ cell epitope engineering: an avian $\mathrm{H} 7 \mathrm{~N} 9$ influenza vaccine strategy for pandemic preparedness and response. Hum Vaccin Immunother 14: 2203-2207. doi:10.1080/ 21645515.2018.1495303

Moody MA, Zhang R, Walter EB, Woods CW, Ginsburg GS, McClain MT, Denny TN, Chen X, Munshaw S, Marshall DJ, et al. 2011. H3N2 influenza infection elicits more cross-reactive and less clonally expanded anti-hemagglutinin antibodies than influenza vaccination. PLOS ONE 6: e25797. doi:10.1371/journal.pone.0025797
Moran I, Nguyen A, Khoo WH, Butt D, Bourne K, Young C, Hermes JR, Biro M, Gracie G, Ma CS, et al. 2018. Memory $\mathrm{B}$ cells are reactivated in subcapsular proliferative foci of lymph nodes. Nat Commun 9: 3372. doi:10.1038/s41467018-05772-7

Morita R, Schmitt N, Bentebibel SE, Ranganathan R, Bourdery L, Zurawski G, Foucat E, Dullaers M, Oh S, Sabzghabaei N, et al. 2011. Human blood $\mathrm{CXCR}^{+} \mathrm{CD}^{+} \mathrm{T}$ cells are counterparts of $\mathrm{T}$ follicular cells and contain specific subsets that differentially support antibody secretion. Immunity 34: 108-121. doi:10.1016/j.immuni.2010 .12 .012

Moriyama M, Chen IY, Kawaguchi A, Koshiba T, Nagata K, Takeyama H, Hasegawa H, Ichinohe T. 2016. The RNAand TRIM25-binding domains of influenza virus NS1 protein are essential for suppression of NLRP 3 inflammasome-mediated interleukin-1 $\beta$ secretion. J Virol 90: 4105-4114. doi:10.1128/JVI.00120-16

Mosmann TR, Naim I, Rebhahn J, Datta S, Cavenaugh JS, Weaver JM, Sharma G. 2014. SWIFT-scalable clustering for automated identification of rare cell populations in large, high-dimensional flow cytometry datasets, part 2: biological evaluation. Cytometry Part A 85: 422-433. doi:10.1002/cyto.a.22445

Nayak JL, Alam S, Sant AJ. 2013a. Cutting edge: heterosubtypic influenza infection antagonizes elicitation of immunological reactivity to hemagglutinin. J Immunol 191: 1001-1005. doi:10.4049/jimmunol.1203520

Nayak JL, Fitzgerald TF, Richards KA, Yang H, Treanor JJ, Sant AJ. 2013b. CD4 ${ }^{+}$T-cell expansion predicts neutralizing antibody responses to monovalent, inactivated 2009 pandemic influenza $A(\mathrm{H} 1 \mathrm{~N} 1)$ virus subtype $\mathrm{H} 1 \mathrm{~N} 1$ vaccine. J Infect Dis 207: 297-305. doi:10.1093/infdis/jis684

Nayak JL, Richards KA, Yang H, Treanor JJ, Sant AJ. 2015. Effect of influenza $\mathrm{A}(\mathrm{H} 5 \mathrm{~N} 1)$ vaccine prepandemic priming on $\mathrm{CD}^{+}{ }^{+} \mathrm{T}$-cell responses. J Infect Dis 211: 14081417. doi:10.1093/infdis/jiu616

Nemeroff ME, Barabino SM, Li Y, Keller W, Krug RM. 1998. Influenza virus NS1 protein interacts with the cellular 30 $\mathrm{kDa}$ subunit of CPSF and inhibits $3^{\prime}$ end formation of cellular pre-mRNAs. Mol Cell 1: 991-1000. doi:10.1016/ S1097-2765(00)80099-4

Neu KE, Henry Dunand CJ, Wilson PC. 2016. Heads, stalks and everything else: how can antibodies eradicate influenza as a human disease? Curr Opin Immunol 42: 48-55. doi:10.1016/j.coi.2016.05.012

Nish SA, Zens KD, Kratchmarov R, Lin WW, Adams WC, Chen YH, Yen B, Rothman NJ, Bhandoola A, Xue HH, et al. 2017. $\mathrm{CD}^{+} \mathrm{T}$ cell effector commitment coupled to self-renewal by asymmetric cell divisions. J Exp Med 214: 39-47. doi:10.1084/jem.20161046

Noah DL, Twu KY, Krug RM. 2003. Cellular antiviral responses against influenza $\mathrm{A}$ virus are countered at the posttranscriptional level by the viral NS1A protein via its binding to a cellular protein required for the $3^{\prime}$ end processing of cellular pre-mRNAS. Virology 307: 386395. doi:10.1016/S0042-6822(02)00127-7

Nogales A, Baker SF, Ortiz-Riano E, Dewhurst S, Topham DJ, Martinez-Sobrido L. 2014. Influenza A virus attenuation by codon deoptimization of the NS gene for vaccine development. J Virol 88: 10525-10540. doi:10.1128/JVI .01565-14 
D.J. Topham et al.

Nogales A, Chauché C, DeDiego ML, Topham DJ, Parrish CR, Murcia PR, Martinez-Sobrido L. 2017a. The K186E amino acid substitution in the canine influenza virus H3N8 NS1 protein restores its ability to inhibit host gene expression. J Virol 91: e00877-17. doi:10.1128/ JVI.00877-17

Nogales A, Martinez-Sobrido L, Topham DJ, DeDiego ML 2017b. NS1 protein amino acid changes D189N and V194I affect interferon responses, thermosensitivity, and virulence of circulating H3N2 human influenza A viruses. J Virol 91: e01930-16. doi:10.1128/JVI.01930-16

Nogales A, Rodriguez L, DeDiego ML, Topham DJ, Martinez-Sobrido L. 2017c. Interplay of PA-X and NS1 proteins in replication and pathogenesis of a temperature-sensitive 2009 pandemic H1N1 influenza A virus. J Virol 91: e00720-17. doi:10.1128/JVI.00720-17

Nogales A, Martinez-Sobrido L, Chiem K, Topham DJ, DeDiego ML. 2018a. Functional evolution of the 2009 pandemic H1N1 influenza virus NS1 and PA in humans. J Virol 92: e01206-18. doi:10.1128/JVI.01206-18

Nogales A, Martinez-Sobrido L, Topham DJ, DeDiego ML. 2018b. Modulation of innate immune responses by the influenza A NS1 and PA-X proteins. Viruses 10: 708. doi:10.3390/v10120708

Nurieva RI, Chung Y, Hwang D, Yang XO, Kang HS, Ma L, Wang YH, Watowich SS, Jetten AM, Tian Q, et al. 2008. Generation of $\mathrm{T}$ follicular helper cells is mediated by interleukin-21 but independent of T helper 1, 2, or 17 cell lineages. Immunity 29: 138-149. doi:10.1016/j.immuni .2008 .05 .009

Nurieva RI, Chung Y, Martinez GJ, Yang XO, Tanaka S, Matskevitch TD, Wang YH, Dong C. 2009. Bcl6 mediates the development of T follicular helper cells. Science 325: 1001-1005. doi:10.1126/science.1176676

Oishi K, Yamayoshi S, Kawaoka Y. 2015. Mapping of a region of the PA-X protein of influenza A virus that is important for its shutoff activity. J Virol 89: 8661-8665. doi:10.1128/JVI.01132-15

Oishi K, Yamayoshi S, Kawaoka Y. 2018. Identification of novel amino acid residues of influenza virus $\mathrm{PA}-\mathrm{X}$ that are important for PA-X shutoff activity by using yeast. Virology 516: 71-75. doi:10.1016/j.virol.2018.01.004

Oja AE, Vieira Braga FA, Remmerswaal EB, Kragten NA, Hertoghs KM, Zuo J, Moss PA, van Lier RA, van Gisbergen KP, Hombrink P. 2017. The transcription factor hobit identifies human cytotoxic $\mathrm{CD} 4^{+} \mathrm{T}$ cells. Front Immunol 8: 325. doi:10.3389/fimmu.2017.00325

Oja AE, Piet B, Helbig C, Stark R, van der Zwan D, Blaauwgeers H, Remmerswaal EBM, Amsen D, Jonkers RE, Moerland PD, et al. 2018. Trigger-happy resident memory $\mathrm{CD}^{+} \mathrm{T}$ cells inhabit the human lungs. Mucosal Immunol 11: 654-667. doi:10.1038/mi.2017.94

Ong JD, Mansell A, Tate MD. 2017. Hero turned villain: NLRP3 inflammasome-induced inflammation during influenza A virus infection. J Leukoc Biol 101: 863-874. doi:10.1189/jlb.4MR0616-288R

Opitz B, Rejaibi A, Dauber B, Eckhard J, Vinzing M, Schmeck B, Hippenstiel S, Suttorp N, Wolff T. 2007. IFN $\beta$ induction by influenza $A$ virus is mediated by RIG-I which is regulated by the viral NS1 protein. Cell Microbiol 9: 930-938. doi:10.1111/j.1462-5822.2006 $.00841 . \mathrm{x}$
Oxford JS. 2013. Towards a universal influenza vaccine: volunteer virus challenge studies in quarantine to speed the development and subsequent licensing. Br J Clin Pharmacol 76: 210-216. doi:10.1111/bcp.12146

Parham P. 1988. Function and polymorphism of human leukocyte antigen-A,B,C molecules. Am J Med 85: 2-5. doi:10.1016/0002-9343(88)90369-5

Park HS, Liu G, Thulasi Raman SN, Landreth SL, Liu Q, Zhou Y. 2018. NS1 protein of 2009 pandemic influenza A virus inhibits Porcine NLRP3 inflammasome-mediated interleukin-1 $\beta$ production by suppressing ASC ubiquitination. J Virol 92: e00022-18. doi:10.1128/JVI.00022-18

Park ES, Byun YH, Park S, Jang YH, Han WR, Won J, Cho KC, Kim DH, Lee AR, Shin GC, et al. 2019. Co-degradation of interferon signaling factor DDX3 by PB1-F2 as a basis for high virulence of 1918 pandemic influenza. EMBO J 38: e99475. doi: 10.1128/JVI.00022-18

Patel RC, Sen GC. 1998. PACT, a protein activator of the interferon-induced protein kinase, PKR. EMBO J 17: 4379-4390. doi:10.1093/emboj/17.15.4379

Paules CI, Marston HD, Eisinger RW, Baltimore D, Fauci AS. 2017. The pathway to a universal influenza vaccine. Immunity 47: 599-603. doi:10.1016/j.immuni.2017.09 .007

Petrova VN, Russell CA. 2018. The evolution of seasonal influenza viruses. Nat Rev Microbiol 16: 47-60. doi:10 $.1038 /$ nrmicro. 2017.118

Pichyangkul S, Yongvanitchit K, Limsalakpetch A, KumArb U, Im-Erbsin R, Boonnak K, Thitithayanont A, Jongkaewwattana A, Wiboon-ut S, Mongkolsirichaikul D, et al. 2015. Tissue distribution of memory $\mathrm{T}$ and $\mathrm{B}$ cells in rhesus monkeys following influenza A infection. J Im munol 195: 4378-4386. doi:10.4049/jimmunol.1501702

Piet B, de Bree GJ, Smids-Dierdorp BS, van der Loos CM, Remmerswaal EB, von der Thusen JH, van Haarst JM, Eerenberg JP, ten Brinke A, van der Bij W, et al. 2011. $\mathrm{CD}^{+} \mathrm{T}$ cells with an intraepithelial phenotype upregulate cytotoxic function upon influenza infection in human lung. J Clin Invest 121: 2254-2263. doi:10.1172/JCI44675

Pilkinton MA, Nicholas KJ, Warren CM, Smith RM, Yoder SM, Talbot HK, Kalams SA. 2017. Greater activation of peripheral $\mathrm{T}$ follicular helper cells following high dose influenza vaccine in older adults forecasts seroconversion. Vaccine 35: 329-336. doi:10.1016/j.vaccine.2016.11.059

Pinar A, Dowling JK, Bitto NJ, Robertson AA, Latz E, Stewart CR, Drummond GR, Cooper MA, McAuley JL, Tate MD, et al. 2017. PB1-F2 peptide derived from avian influenza A virus $\mathrm{H} 7 \mathrm{~N} 9$ induces inflammation via activation of the NLRP3 inflammasome. J Biol Chem 292: 826-836. doi:10 $.1074 /$ jbc.M116.756379

Pleguezuelos O, Robinson S, Fernández A, Stoloff GA, Mann A, Gilbert A, Balaratnam G, Wilkinson T, Lambkin-Williams R, Oxford J, et al. 2015. A synthetic influenza virus vaccine induces a cellular immune response that correlates with reduction in symptomatology and virus shedding in a randomized phase Ib live-virus challenge in humans. Clin Vaccine Immunol 22: 828-835. doi:10 .1128/CVI.00098-15

Pulendran B, Maddur MS. 2015. Innate immune sensing and response to influenza. Curr Top Microbiol Immunol 386: 23-71. 
Purwar R, Campbell J, Murphy G, Richards WG, Clark RA, Kupper TS. 2011. Resident memory T cells $\left(\mathrm{T}_{\mathrm{RM}}\right)$ are abundant in human lung: diversity, function, and antigen specificity. PLOS ONE 6: e16245. doi:10.1371/journal .pone. 0016245

Quinones-Parra S, Grant E, Loh L, Nguyen TH, Campbell KA, Tong SY, Miller A, Doherty PC, Vijaykrishna D, Rossjohn J, et al. 2014. Preexisting CD8 ${ }^{+} \mathrm{T}$-cell immunity to the H7N9 influenza A virus varies across ethnicities. Proc Natl Acad Sci 111: 1049-1054. doi:10.1073/pnas .1322229111

Rajsbaum R, Albrecht RA, Wang MK, Maharaj NP, Versteeg GA, Nistal-Villán E, García-Sastre A, Gack MU. 2012. Species-specific inhibition of RIG-I ubiquitination and IFN induction by the influenza A virus NS1 protein. PLoS Pathog 8: e1003059. doi:10.1371/journal.ppat .1003059

Ramos I, Smith G, Ruf-Zamojski F, Martínez-Romero C, Fribourg M, Carbajal EA, Hartmann BM, Nair VD, Marjanovic N, Monteagudo PL, et al. 2019. Innate immune response to influenza virus at single-cell resolution in human epithelial cells revealed paracrine induction of interferon lambda 1. J Virol 93: e00559-19. doi:10.1128/ JVI.00559-19

Ray SJ, Franki SN, Pierce RH, Dimitrova S, Koteliansky V, Sprague AG, Doherty PC, de Fougerolles AR, Topham DJ. 2004. The collagen binding $\alpha 1 \beta 1$ integrin VLA-1 regulates CD8 T cell-mediated immune protection against heterologous influenza infection. Immunity 20: 167-179. doi:10.1016/S1074-7613(04)00021-4

Richards KA, Chaves FA, Sant AJ. 2009. Infection of HLADR1 transgenic mice with a human isolate of influenza a virus (H1N1) primes a diverse $\mathrm{CD} 4 \mathrm{~T}$-cell repertoire that includes CD4 T cells with heterosubtypic cross-reactivity to avian (H5N1) influenza virus. J Virol 83: 6566-6577. doi:10.1128/JVI.00302-09

Richards KA, Topham D, Chaves FA, Sant AJ. 2010. Cutting edge: CD4 T cells generated from encounter with seasonal influenza viruses and vaccines have broad protein specificity and can directly recognize naturally generated epitopes derived from the live pandemic H1N1 virus. J Immunol 185: 4998-5002. doi:10.4049/jimmunol .1001395

Richards KA, Nayak J, Chaves FA, DiPiazza A, Knowlden ZA, Alam S, Treanor JJ, Sant AJ. 2015. Seasonal influenza can poise hosts for CD4 T-cell immunity to H7N9 avian influenza. J Infect Dis 212: 86-94. doi:10.1093/infdis/ jiu662

Richards KA, Treanor JJ, Nayak JL, Sant AJ. 2018. Overarching immunodominance patterns and substantial diversity in specificity and functionality in the circulating human influenza A and B CD4T cell repertoire. J Infect Dis 218: 1169-1174. doi: 10.1093/infdis/jiy288

Richter M, Ray SJ, Chapman TJ, Austin SJ, Rebhahn J, Mosmann TR, Gardner H, Kotelianski V, deFougerolles AR, Topham DJ. 2007. Collagen distribution and expression of collagen-binding $\alpha_{1} \beta_{1}$ (VLA-1) and $\alpha_{2} \beta_{1}$ (VLA-2) integrins on CD4 and CD8T cells during influenza infection. J Immunol 178: 4506-4516. doi:10.4049/jimmunol .178 .7 .4506
Rimmelzwaan GF, McElhaney JE. 2008. Correlates of protection: novel generations of influenza vaccines. Vaccine 26: D41-D44. doi:10.1016/j.vaccine.2008.07.043

Rimmelzwaan GF, Kreijtz JH, Bodewes R, Fouchier RA, Osterhaus AD. 2009. Influenza virus CTL epitopes, remarkably conserved and remarkably variable. Vaccine 27: 6363-6365. doi:10.1016/j.vaccine.2009.01.016

Rosato PC, Beura LK, Masopust D. 2017. Tissue resident memory $\mathrm{T}$ cells and viral immunity. Curr Opin Virol 22: 44-50. doi:10.1016/j.coviro.2016.11.011

Roti M, Yang J, Berger D, Huston L, James EA, Kwok WW. 2008. Healthy human subjects have $\mathrm{CD} 4^{+} \mathrm{T}$ cells directed against H5N1 influenza virus. J Immunol 180: 17581768. doi:10.4049/jimmunol.180.3.1758

Roumanes D, Falsey AR, Quataert S, Secor-Socha S, Lee FE, Yang H, Bandyopadhyay S, Holden-Wiltse J, Topham DJ, Walsh EE. 2018. T-cell responses in adults during natural respiratory syncytial virus infection. J Infect Dis 218: 418428. doi:10.1093/infdis/jiy016

Sallusto F, Lenig D, Förster R, Lipp M, Lanzavecchia A. 1999. Two subsets of memory $\mathrm{T}$ lymphocytes with distinct homing potentials and effector functions [see comments]. Nature 401: 708-712. doi:10.1038/44385

Salmi M, Alanen K, Grenman S, Briskin M, Butcher EC, Jalkanen S. 2001. Immune cell trafficking in uterus and early life is dominated by the mucosal addressin MAdCAM-1 in humans. Gastroenterology 121: 853864. doi:10.1053/gast.2001.27968

Sangster MY, Nguyen PQT, Topham DJ. 2019. Role of memory $\mathrm{B}$ cells in hemagglutinin-specific antibody production following human influenza A virus infection. Pathogens 8: 167. doi:10.3390/pathogens 8040167

Sant AJ, McMichael A. 2012. Revealing the role of $\mathrm{CD}^{+} \mathrm{T}$ cells in viral immunity. J Exp Med 209: 1391-1395. doi:10 $.1084 /$ jem. 20121517

Sant AJ, DiPiazza AT, Nayak JL, Rattan A, Richards KA. 2018a. CD4 T cells in protection from influenza virus: viral antigen specificity and functional potential. Immunol Rev 284: 91-105. doi:10.1111/imr.12662

Sant S, Grzelak L, Wang Z, Pizzolla A, Koutsakos M, Crowe J, Loudovaris T, Mannering SI, Westall GP, Wakim LM, et al. 2018b. Single-cell approach to influenza-specific $\mathrm{CD}^{+} \mathrm{T}$ cell receptor repertoires across different age groups, tissues, and following influenza virus infection. Front Immunol 9: 1453. doi:10.3389/fimmu.2018.01453

Satterly N, Tsai PL, van Deursen J, Nussenzveig DR, Wang Y, Faria PA, Levay A, Levy DE, Fontoura BM. 2007. Influenza virus targets the mRNA export machinery and the nuclear pore complex. Proc Natl Acad Sci 104: 18531858. doi:10.1073/pnas.0610977104

Savic M, Dembinski JL, Kim Y, Tunheim G, Cox RJ, Oftung F, Peters B, Mjaaland S. 2016. Epitope specific T-cell responses against influenza $\mathrm{A}$ in a healthy population. Immunology 147: 165-177. doi:10.1111/imm. 12548

Schaerli P, Willimann K, Lang AB, Lipp M, Loetscher P, Moser B. 2000. CXC chemokine receptor 5 expression defines follicular homing T cells with B cell helper function. J Exp Med 192: 1553-1562. doi:10.1084/jem.192.11 .1553

Scheible KM, Emo J, Yang H, Holden-Wiltse J, Straw A, Huyck H, Misra S, Topham DJ, Ryan RM, Reynolds AM, et al. 2015. Developmentally determined reduction 
D.J. Topham et al.

in CD31 during gestation is associated with $\mathrm{CD} 8^{+} \mathrm{T}$ cell effector differentiation in preterm infants. Clin Immunol 161: 65-74. doi:10.1016/j.clim.2015.07.003

Scheible KM, Emo J, Laniewski N, Baran AM, Peterson DR, Holden-Wiltse J, Bandyopadhyay S, Straw AG, Huyck H, Ashton JM, et al. 2018. T cell developmental arrest in former premature infants increases risk of respiratory morbidity later in infancy. JCI Insight 3. doi:10.1172/jci .insight.96724

Schierhorn KL, Jolmes F, Bespalowa J, Saenger S, Peteranderl C, Dzieciolowski J, Mielke M, Budt M, Pleschka S, Herrmann A, et al. 2017. Influenza A virus virulence depends on two amino acids in the N-terminal domain of its NS1 protein to facilitate inhibition of the RNA-dependent protein kinase PKR. J Virol 91: e00198-17. doi:10.1128/ JVI.00198-17

Schmidt ME, Varga SM. 2018. The CD8 T cell response to respiratory virus infections. Front Immunol 9: 678. doi:10 $.3389 /$ fimmu.2018.00678

Shen Z, Chen Z, Li X, Xu L, Guan W, Cao Y, Hu Y, Zhang J. 2014. Host immunological response and factors associated with clinical outcome in patients with the novel influenza A H7N9 infection. Clin Microbiol Infect 20: O493-O500. doi:10.1111/1469-0691.12505

Shi M, Jagger BW, Wise HM, Digard P, Holmes EC, Taubenberger JK. 2012. Evolutionary conservation of the PA-X open reading frame in segment 3 of influenza A virus. J Virol 86: 12411-12413. doi:10.1128/JVI.01677-12

Sicca F, Neppelenbroek S, Huckriede A. 2018. Effector mechanisms of influenza-specific antibodies: neutralization and beyond. Expert Rev Vaccines 17: 785-795. doi:10 $.1080 / 14760584.2018 .1516553$

Siegelman MH, Stanescu D, Estess P. 2000. The CD44-initiated pathway of T-cell extravasation uses VLA-4 but not LFA-1 for firm adhesion. J Clin Invest 105: 683-691. doi:10.1172/JCI8692

Silverman RH, Weiss SR. 2014. Viral phosphodiesterases that antagonize double-stranded RNA signaling to RNase $\mathrm{L}$ by degrading 2-5A. J Interferon Cytokine Res 34: 455463. doi:10.1089/jir.2014.0007

Snyder ME, Finlayson MO, Connors TJ, Dogra P, Senda T, Bush E, Carpenter D, Marboe C, Benvenuto L, Shah L, et al. 2019. Generation and persistence of human tissueresident memory T cells in lung transplantation. Sci Immunol 4: eaav5581.

Spensieri F, Borgogni E, Zedda L, Bardelli M, Buricchi F, Volpini G, Fragapane E, Tavarini S, Finco O, Rappuoli R, et al. 2013. Human circulating influenza-CD4 ${ }^{+}$ ICOS $1^{+} \mathrm{IL}-21^{+} \mathrm{T}$ cells expand after vaccination, exert helper function, and predict antibody responses. Proc Natl Acad Sci 110: 14330-14335. doi:10.1073/pnas 1311998110

Spensieri F, Siena E, Borgogni E, Zedda L, Cantisani R, Chiappini N, Schiavetti F, Rosa D, Castellino F, Montomoli E, et al. 2016. Early rise of blood T follicular helper cell subsets and baseline immunity as predictors of persisting late functional antibody responses to vaccination in humans. PLoS ONE 11: e0157066. doi:10.1371/journal .pone. 0157066

Sprenger H, Meyer RG, Kaufmann A, Bussfeld D, Rischkowsky E, Gemsa D. 1996. Selective induction of monocyte and not neutrophil-attracting chemokines after influenza
A virus infection. J Exp Med 184: 1191-1196. doi:10.1084/ jem.184.3.1191

Sridhar S, Begom S, Bermingham A, Hoschler K, Adamson W, Carman W, Bean T, Barclay W, Deeks JJ, Lalvani A. 2013. Cellular immune correlates of protection against symptomatic pandemic influenza. Nat Med 19: 13051312. doi: $10.1038 / \mathrm{nm} .3350$

Strutt TM, McKinstry KK, Dibble JP, Winchell C, Kuang Y, Curtis JD, Huston G, Dutton RW, Swain SL. 2010. Memory $\mathrm{CD} 4^{+} \mathrm{T}$ cells induce innate responses independently of pathogen. Nat Med 16: 558-564. doi:10.1038/nm.2142

Strutt TM, Dhume K, Finn CM, Hwang JH, Castonguay C, Swain SL, McKinstry KK. 2017. IL-15 supports the generation of protective lung-resident memory CD4 T cells. Mucosal Immunol 11: 668-680. doi:10.1038/mi.2017.101

Suptawiwat O, Kongchanagul A, Boonarkart C, Auewarakul P. 2018. H1N1 seasonal influenza virus evolutionary rate changed over time. Virus Res 250: 43-50. doi:10.1016/j .virusres.2018.03.020

Swain SL, Dutton RW, Woodland DL. 2004. T cell responses to influenza virus infection: effector and memory cells. Viral Immunol 17: 197-209. doi:10.1089/088282 4041310577

Szabo PA, Miron M, Farber DL. 2019. Location, location, location: tissue resident memory T cells in mice and humans. Sci Immunol 4: eaas9673. doi:10.1126/sciimmunol .aas 9673

Takamura S. 2017. Persistence in temporary lung niches: a survival strategy of lung-resident memory $\mathrm{CD} 8^{+} \mathrm{T}$ cells. Viral Immunol 30: 438-450. doi:10.1089/vim.2017.0016

Takamura S. 2018. Niches for the long-term maintenance of tissue-resident memory T cells. Front Immunol 9: 1214. doi:10.3389/fimmu.2018.01214

Takeuchi A, Saito T. 2017. CD4 CTL, a cytotoxic subset of $\mathrm{CD}^{+} \mathrm{T}$ cells, their differentiation and function. Front Immunol 8: 194. doi:10.3389/fimmu.2017.00194

Takeuchi A, Badr Mel S, Miyauchi K, Ishihara C, Onishi R, Guo Z, Sasaki Y, Ike H, Takumi A, Tsuji NM, et al. 2016. CRTAM determines the $\mathrm{CD} 4^{+}$cytotoxic T lymphocyte lineage. J Exp Med 213: 123-138. doi:10.1084/jem.2015 0519

Talon J, Horvath CM, Polley R, Basler CF, Muster T, Palese P, García-Sastre A. 2000a. Activation of interferon regulatory factor 3 is inhibited by the influenza A virus NS1 protein. J Virol 74: 7989-7996. doi:10.1128/JVI.74.17 $.7989-7996.2000$

Talon J, Salvatore M, O'Neill RE, Nakaya Y, Zheng H, Muster T, Garcia-Sastre A, Palese P. 2000b. Influenza A and B viruses expressing altered NS1 proteins: a vaccine approach. Proc Natl Acad Sci 97: 4309-4314. doi:10.1073/ pnas.070525997

Tan GS, Leon PE, Albrecht RA, Margine I, Hirsh A, Bahl J, Krammer F. 2016. Broadly-reactive neutralizing and nonneutralizing antibodies directed against the $\mathrm{H7}$ influenza virus hemagglutinin reveal divergent mechanisms of protection. PLoS Pathog 12: e1005578. doi:10.1371/journal .ppat.1005578

Teijaro JR, Verhoeven D, Page CA, Turner D, Farber DL. 2010. Memory CD4 T cells direct protective responses to influenza virus in the lungs through helper-independent mechanisms. J Virol 84: 9217-9226. doi:10.1128/JVI $.01069-10$ 
Teijaro JR, Turner D, Pham Q, Wherry EJ, Lefrançois L, Farber DL. 2011. Cutting edge: tissue-retentive lung memory CD4 $\mathrm{T}$ cells mediate optimal protection to respiratory virus infection. J Immunol 187: 5510-5514. doi:10.4049/jimmunol.1102243

Tesini BL, Kanagaiah P, Wang J, Hahn M, Halliley JL, Chaves FA, Nguyen PQT, Nogales A, DeDiego ML, Anderson CS, et al. 2019. Broad hemagglutinin-specific memory B cell expansion by seasonal influenza virus infection reflects early-life imprinting and adaptation to the infecting virus. J Virol 93: e00169e00-19. doi:10.1128/JVI.00169-19

To KK, Hung IF, Li IW, Lee KL, Koo CK, Yan WW, Liu R, Ho KY, Chu KH, Watt CL, et al. 2010. Delayed clearance of viral load and marked cytokine activation in severe cases of pandemic H1N1 2009 influenza virus infection. Clin Infect Dis 50: 850-859. doi:10.1086/650581

Topham DJ, Reilly EC. 2018. Tissue-resident memory CD8 ${ }^{+}$ T cells: from phenotype to function. Front Immunol 9: 515. doi:10.3389/fimmu.2018.00515

Topham DJ, Tripp RA, Doherty PC. 1997. CD8 ${ }^{+}$T cells clear influenza virus by perforin or Fas-dependent processes. J Immunol 159: 5197-5200.

Treanor J, Wright PF. 2003. Immune correlates of protection against influenza in the human challenge model. Dev Biol (Basel) 115: 97-104

Tubo NJ, Pagán AJ, Taylor JJ, Nelson RW, Linehan JL, Ertelt JM, Huseby ES, Way SS, Jenkins MK. 2013. Single naive $\mathrm{CD}^{+} \mathrm{T}$ cells from a diverse repertoire produce different effector cell types during infection. Cell 153: 785-796. doi:10.1016/j.cell.2013.04.007

Turner DL, Bickham KL, Farber DL, Lefrancois L. 2013. Splenic priming of virus-specific CD8 T cells following influenza virus infection. J Virol 87: 4496-4506. doi:10 .1128/JVI.03413-12

Tutykhina I, Esmagambetov I, Bagaev A, Pichugin A, Lysenko A, Shcherbinin D, Sedova E, Logunov D, Shmarov M, Ataullakhanov R, et al. 2018. Vaccination potential of B and T epitope-enriched NP and M2 against Influenza A viruses from different clades and hosts. PLoS ONE 13: e0191574. doi:10.1371/journal.pone.0191574

Twu KY, Kuo RL, Marklund J, Krug RM. 2007. The H5N1 influenza virus NS genes selected after 1998 enhance virus replication in mammalian cells. J Virol 81: 8112-8121. doi:10.1128/JVI.00006-07

Uchtenhagen H, Rims C, Blahnik G, Chow IT, Kwok WW, Buckner JH, James EA. 2016. Efficient ex vivo analysis of $\mathrm{CD}^{+} \mathrm{T}$-cell responses using combinatorial HLA class II tetramer staining. Nat Commun 7: 12614. doi:10.1038/ ncomms 12614

Ueno H. 2016. Human circulating T follicular helper cell subsets in health and disease. J Clin Immunol 36 (Suppl 1): 34-39. doi:10.1007/s10875-016-0268-3

Van Braeckel-Budimir N, Martin MD, Hartwig SM, Legge KL, Badovinac VP, Harty JT. 2017. Antigen exposure history defines CD8 T cell dynamics and protection during localized pulmonary infections. Front Immunol 8: 40. doi:10.3389/fimmu.2017.00040

Van Braeckel-Budimir N, Varga SM, Badovinac VP, Harty JT. 2018. Repeated antigen exposure extends the durability of influenza-specific lung-resident memory $\mathrm{CD}^{+} \mathrm{T}$ cells and heterosubtypic immunity. Cell Rep 24: 33743382.e3. doi:10.1016/j.celrep.2018.08.073
Varga ZT, Ramos I, Hai R, Schmolke M, García-Sastre A, Fernandez-Sesma A, Palese P. 2011. The influenza virus protein PB1-F2 inhibits the induction of type I interferon at the level of the MAVS adaptor protein. PLoS Pathog 7: e1002067. doi:10.1371/journal.ppat.1002067

Varga ZT, Grant A, Manicassamy B, Palese P. 2012. Influenza virus protein PB1-F2 inhibits the induction of type I interferon by binding to MAVS and decreasing mitochondrial membrane potential. J Virol 86: 8359-8366. doi:10.1128/JVI.01122-12

Vinuesa CG, Linterman MA, Yu D, MacLennan IC. 2016. Follicular helper T cells. Annu Rev Immunol 34: 335-368. doi:10.1146/annurev-immunol-041015-055605

Voeten JT, Bestebroer TM, Nieuwkoop NJ, Fouchier RA, Osterhaus AD, Rimmelzwaan GF. 2000. Antigenic drift in the influenza A virus (H3N2) nucleoprotein and escape from recognition by cytotoxic T lymphocytes. J Virol 74: 6800-6807. doi:10.1128/JVI.74.15.6800-6807.2000

Wang X, Li M, Zheng H, Muster T, Palese P, Beg AA, GarcíaSastre A. 2000. Influenza A virus NS1 protein prevents activation of NF- $\mathrm{KB}$ and induction of $\alpha / \beta$ interferon. $J$ Virol 74: 11566-11573. doi:10.1128/JVI.74.24.1156611573.2000

Wang Z, Zhang A, Wan Y, Liu X, Qiu C, Xi X, Ren Y, Wang J, Dong Y, Bao M, et al. 2014. Early hypercytokinemia is associated with interferon-induced transmembrane protein-3 dysfunction and predictive of fatal H7N9 infection. Proc Natl Acad Sci 111: 769-774. doi:10.1073/pnas .1321748111

Wang Z, Wan Y, Qiu C, Quiñones-Parra S, Zhu Z, Loh L, Tian D, Ren Y, Hu Y, Zhang X, et al. 2015. Recovery from severe $\mathrm{H} 7 \mathrm{~N} 9$ disease is associated with diverse response mechanisms dominated by $\mathrm{CD} 8^{+} \mathrm{T}$ cells. Nat Commun 6: 6833 . doi: $10.1038 /$ ncomms 7833

Weinfurter JT, Brunner K, Capuano SV 3rd, Li C, Broman KW, Kawaoka Y, Friedrich TC. 2011. Cross-reactive T cells are involved in rapid clearance of 2009 pandemic H1N1 influenza virus in nonhuman primates. PLoS Pathog 7: e1002381. doi:10.1371/journal.ppat.1002381

Weisel Florian J, Zuccarino-Catania Griselda V, Chikina M, Shlomchik Mark J. 2016. A temporal switch in the germinal center determines differential output of memory B and plasma cells. Immunity 44: 116-130. doi:10.1016/j .immuni.2015.12.004

Wilkinson TM, Li CK, Chui CS, Huang AK, Perkins M, Liebner JC, Lambkin-Williams R, Gilbert A, Oxford J, Nicholas B, et al. 2012. Preexisting influenza-specific $\mathrm{CD}^{+} \mathrm{T}$ cells correlate with disease protection against influenza challenge in humans. Nat Med 18: 274-280. doi: $10.1038 / \mathrm{nm} .2612$

Wohlbold TJ, Nachbagauer R, Xu H, Tan GS, Hirsh A, Brokstad KA, Cox RJ, Palese P, Krammer F. 2015. Vaccination with adjuvanted recombinant neuraminidase induces broad heterologous, but not heterosubtypic, cross-protection against influenza virus infection in mice. mBio 6: e02556. doi:10.1128/mBio.02556-14

Wohlbold TJ, Podolsky KA, Chromikova V, Kirkpatrick E, Falconieri V, Meade P, Amanat F, Tan J, tenOever BR, Tan GS, et al. 2017. Broadly protective murine monoclonal antibodies against influenza B virus target highly conserved neuraminidase epitopes. Nat Microbiol 2: 1415-1424. doi:10.1038/s41564-017-0011-8 
D.J. Topham et al.

Wong SS, Oshansky CM, Guo XJ, Ralston J, Wood T, Seeds R, Newbern C, Waite B, Reynolds G, Widdowson MA, et al. 2018. Severe influenza is characterized by prolonged immune activation: results from the SHIVERS Cohort Study. J Infect Dis 217: 245-256. doi:10.1093/infdis/ jix571

Woodland DL, Ely KH, Crowe SR, Tighe M, Brennan JW, Harmsen AG, Cauley LS. 2002. Antiviral memory T-cell responses in the lung. Microbes Infect 4: 1091-1098. doi:10.1016/S1286-4579(02)01633-7

Workman AM, Jacobs AK, Vogel AJ, Condon S, Brown DM. 2014. Inflammation enhances IL-2 driven differentiation of cytolytic CD4T cells. PLoS ONE 9: e89010. doi:10 .1371/journal.pone.0089010

Wrammert J, Koutsonanos D, Li GM, Edupuganti S, Sui J, Morrissey M, McCausland M, Skountzou I, Hornig M, Lipkin WI, et al. 2011. Broadly cross-reactive antibodies dominate the human B cell response against 2009 pandemic H1N1 influenza virus infection. J Exp Med 208: 181-193. doi:10.1084/jem.20101352

Wu NC, Wilson IA. 2018. Structural insights into the design of novel anti-influenza therapies. Nat Struct Mol Biol 25: 115-121. doi:10.1038/s41594-018-0025-9

Wu H, Kumar A, Miao H, Holden-Wiltse J, Mosmann TR, Livingstone AM, Belz GT, Perelson AS, Zand MS, Topham DJ. 2011. Modeling of influenza-specific $\mathrm{CD} 8^{+} \mathrm{T}$ cells during the primary response indicates that the spleen is a major source of effectors. J Immunol 187: 4474-4482. doi:10.4049/jimmunol.1101443

Yamasaki S, Shimizu K, Kometani K, Sakurai M, Kawamura M, Fujii SI. 2016. In vivo dendritic cell targeting cellular vaccine induces $\mathrm{CD}^{+}$Tfh cell-dependent antibody against influenza virus. Sci Rep 6: 35173. doi:10.1038/ srep35173

Yoo JK, Fish EN, Braciale TJ. 2012. LAPCs promote follicular helper $\mathrm{T}$ cell differentiation of Ag-primed $\mathrm{CD} 4^{+} \mathrm{T}$ cells during respiratory virus infection. J Exp Med 209: 1853 1867. doi:10.1084/jem.20112256

Yoon H, Legge KL, Sung SS, Braciale TJ. 2007. Sequential activation of $\mathrm{CD}^{+} \mathrm{T}$ cells in the draining lymph nodes in response to pulmonary virus infection. J Immunol 179: 391-399. doi:10.4049/jimmunol.179.1.391

Yoshizumi T, Ichinohe T, Sasaki O, Otera H, Kawabata S, Mihara K, Koshiba T. 2014. Influenza A virus protein
PB1-F2 translocates into mitochondria via Tom40 channels and impairs innate immunity. Nat Commun 5: 4713. doi:10.1038/ncomms5713

Yu D, Rao S, Tsai LM, Lee SK, He Y, Sutcliffe EL, Srivastava M, Linterman M, Zheng L, Simpson N, et al. 2009. The transcriptional repressor Bcl-6 directs $\mathrm{T}$ follicular helper cell lineage commitment. Immunity 31: 457-468. doi:10 .1016/j.immuni.2009.07.002

Yuan P, Bartlam M, Lou Z, Chen S, Zhou J, He X, Lv Z, Ge R, Li X, Deng T, et al. 2009. Crystal structure of an avian influenza polymerase $\mathrm{PA}_{\mathrm{N}}$ reveals an endonuclease active site. Nature 458: 909-913. doi:10.1038/nature07720

Zaiss DMW, Gause WC, Osborne LC, Artis D. 2015. Emerging functions of amphiregulin in orchestrating immunity, inflammation, and tissue repair. Immunity 42: 216-226. doi:10.1016/j.immuni.2015.01.020

Zamarin D, García-Sastre A, Xiao X, Wang R, Palese P. 2005 Influenza virus $\mathrm{PB} 1-\mathrm{F} 2$ protein induces cell death through mitochondrial ANT3 and VDAC1. PLoS Pathog 1: e4. doi:10.1371/journal.ppat.0010004

Zens KD, Chen JK, Farber DL. 2016. Vaccine-generated lung tissue-resident memory $\mathrm{T}$ cells provide heterosubtypic protection to influenza infection. JCI Insight 1: 85832.

Zens KD, Chen JK, Guyer RS, Wu FL, Cvetkovski F, Miron M, Farber DL. 2017. Reduced generation of lung tissueresident memory T cells during infancy. J Exp Med 214: 2915-2932. doi:10.1084/jem.20170521

Zhao Z, Yi C, Zhao L, Wang S, Zhou L, Hu Y, Zou W, Chen H, Jin M. 2014. PB2-588I enhances 2009 H1N1 pandemic influenza virus virulence by increasing viral replication and exacerbating PB2 inhibition of $\beta$ interferon expression. J Virol 88: 2260-2267. doi:10.1128/JVI.03024-13

Zhao Y, Uduman M, Siu JHY, Tull TJ, Sanderson JD, Wu YCB, Zhou JQ, Petrov N, Ellis R, Todd K, et al. 2018. Spatiotemporal segregation of human marginal zone and memory B cell populations in lymphoid tissue. Nat Commun 9: 3857. doi:10.1038/s41467-018-06089-1

Zost SJ, Wu NC, Hensley SE, Wilson IA. 2019. Immunodominance and antigenic variation of influenza virus hemagglutinin: implications for design of universal vaccine immunogens. J Infect Dis 219: S38-S45. doi:10.1093/in fdis/jiy696 


\section{$\&_{\mathrm{CSH}}^{\infty} \&$ Cold Spring Harbor

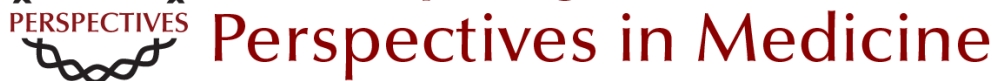

\section{Immunity to Influenza Infection in Humans}

David J. Topham, Marta L. DeDiego, Aitor Nogales, Mark Y. Sangster and Andrea Sant

Cold Spring Harb Perspect Med 2021; doi: 10.1101/cshperspect.a038729 originally published online December 23, 2019

\section{Subject Collection Influenza: The Cutting Edge}

\section{Emerging HxNy Influenza A Viruses} William J. Liu, Yan Wu, Yuhai Bi, et al.

Equine Influenza

Thomas M. Chambers

\section{Human Influenza Epidemiology \\ Sukhyun Ryu and Benjamin J. Cowling}

Host Cell Factors That Interact with Influenza

Virus Ribonucleoproteins

Ecco Staller and Wendy S. Barclay

Induction and Evasion of Type-I Interferon

Responses during Influenza A Virus Infection

Raquel Muñoz-Moreno, Carles Martínez-Romero and Adolfo García-Sastre

Structure and Function of Influenza Polymerase Joanna M. Wandzik, Tomas Kouba and Stephen Cusack

H7N9 Influenza Virus in China Chengjun Li and Hualan Chen

H5 Influenza Viruses in Egypt Rabeh El-Shesheny, Ahmed Kandeil, Ahmed Mostafa, et al.
Antivirals Targeting the Neuraminidase Larisa Gubareva and Teena Mohan

Accessory Gene Products of Influenza A Virus Rute M. Pinto, Samantha Lycett, Eleanor Gaunt, et al.

Influenza Immunization in the Context of

Preexisting Immunity Susanne L. Linderman, Ali H. Ellebedy, Carl Davis, et al.

Hemagglutinin Structure and Activities Steven J. Gamblin, Sébastien G. Vachieri, Xiaoli Xiong, et al.

Live Attenuated Cold-Adapted Influenza Vaccines Kanta Subbarao

Next-Generation Influenza Vaccines Masaru Kanekiyo and Barney S. Graham

Selective Genome Packaging Mechanisms of Influenza A Viruses Takeshi Noda

Systems Biological Analysis of Immune Response to Influenza Vaccination Mario Cortese, Amy C. Sherman, Nadine G. Rouphael, et al.

For additional articles in this collection, see http://perspectivesinmedicine.cshlp.org/cgi/collection/ 